\title{
Asker Kökenli Yassıada Sanıklarının 27 Mayıs Darbesi Öncesindeki Konumları ve İadeiitibarlarına Giden Süreç: 1950 - 1967
}

\section{Position of the Military-Based Yassiada Defendants before the 1960 Coup and the Restoration of Their Honor: 1950 - 1967}

\author{
Sacit YARIMOĞLU* (1)
}

*Dr., Adana, Türkiye

ORCID: S.Y. 0000-0001-5366-6680

Sorumlu yazar/Corresponding author: Sacit Yarımoğlu,

Adana, Türkiye

E-posta/E-mail:: sacit_yarimoglu@hotmail. com

Başvuru/Submitted: 01.10.2020 Revizyon Talebi/Revision Requested: 14.10.2020

Son Revizyon/Last Revision Received: 05.06.2021

Kabul/Accepted: 07.06.2021

Atıf/Citation: Yarımoglu, Sacit. “Asker Kökenli Yassıada Sanıklarının 27 Mayıs Darbesi Öncesindeki Konumları ve ladeiitibarlarına Giden Süreç: 1950 - 1967." Yakın Dönem Türkiye Araştırmaları-Recent Period Turkish Studies 40 (2021): 213-250. https://doi.org/10.26650/YTA2021-803958
ÖZ

Bu makalede, 27 Mayıs 1960 Darbesi'nden etkilenen mevcut ordu üst yönetimi ya da emekli konumda DP'den siyasete atılmış asker kökenli milletvekillerinin darbe sonrasındaki durumları incelenecektir. Makalenin kapsamı içerisinde üç önemli kırılma noktası vardır. Birincisi DP'nin 1950 y1lında iktidar olmasıyla birlikte TSK'yla kurduğu ilişkilerdir. İkincisi 1960 yılında DP ile birlikte hareket eden ordu üyelerinin, 27 Mayıs Darbesi'nin gerçekleşmesine -cuntacılara göreolan etkileridir. Çünkü onlar, en çok bu yönleriyle cuntacıların dikkatini -olumsuz anlamda- çekeceklerdir. 1960-1967 yılları arasındaki gelişmeler ise asker kökenli milletvekillerinin ya da 27 Mays Darbesi öncesinde ordu üst kademesinde bulunan bazı generallerin Yassıada'da yargılanmaları ve ceza almaları sonucunda alınan rütbelerinin, kendilerine iade edilmesiyle sonlanmıştır.

Anahtar Kelimeler: 27 Mayıs Darbesi, Asker Bürokratlar, Demokrat Parti, Asker Kökenli Siyasiler, Yassıada

\section{ABSTRACT}

This article examines the post-coup situation of the current army senior administration or military-based deputies who had retired from the army and been thrown into politics within the Democrat Party (DP). There are three important break points noted in this article. The first relates to the relationships that the DP established with the Turkish Armed Forces when it came to power in 1950. The second concerns the effects of the actions of army personnel who acted together with the DP on the realization of the 1960 coup with regard to the junta, as they attracted the attention of the junta in a negative sense. Lastly, the developments between 1960 and 1967 consequently ended with the recovery of the ranks taken from the military-based deputies or generals who had been in the upper echelon of the army before the 1960 coup, after being convicted and sentenced in Yassiada trials.

Keywords: The 1960 Turkish Coup, Military Bureaucrats, Democrat Party, Military-Based Politicians, Yassıada 


\section{Extended Abstract}

The DP embodied hope both for those tired of the one-party regime and for some officers in the army. Although Turkey was one of the few countries in Europe to avoid major damage in World War II due to İsmet İnönü's leadership, it had shouldered an additional economic burden due to the war, and this was perhaps harder for the military than for other members of the public. Thus, one reason for the May 27 coup was the low social status of military personnel due to economic difficulties. Immediately after the war, the reaction was directed against the CHP (Republican People's Party) for the period of $1946-1950$. This necessitated examining the attitude of some army members toward the CHP. The CHP, which founded modern Turkey, was dominant in the military before turning to the DP. Alternatively, the positions of military bureaucrats during the DP period acted as triggers for the events that led to the 1960 coup. This caused polarization within the army and differences of opinion between the members of the army who followed a management approach in favor of the DP and those who did not. Several groups reacted against the DP during the 1950-1960 period, including intellectuals, civil bureaucrats, and some of the press members. As a matter of fact, especially in the second half of the 1950s, the economic policies followed by the DP led part of the public to react against the DP government. Parallel to this, the pressure exerted by the DP to take control of the social sphere resulted in reverberations among universities and thus students, which in turn, resulted in protests, mostly among the young people. Therefore, as the coup began to develop, these protests were severely suppressed by the senior management of the military, who acted in favor of the DP, with the exception of the police forces. Therefore, the military coup of May 27 was largely conducted by lower-ranking personnel.

Commander of the Turkish Armed Forces Rüştü Erdelhun was brought down from the administration is also important in this context. This article investigates the 1960 coup in a novel way, asking the main question, "Have military command echelon been sufficiently emphasized in the study of military coups?" In fact, the aforementioned issue -after the dismissal process of the superiors- has not been sufficiently emphasized, as the main issue investigated in relation to coups is the governments that are overthrown. In our case, the people most commonly mentioned in the 1960 coup context are a few powerful people in the DP. After the military coup of May 27, 1960, however, not only the military cadres who supported DP, but also politicians, bureaucrats, journalists, and others were affected from the coup process and Yassiada trials. For these groups, the injustices in the Yassiada trials are obvious. Therefore, both Yassiada defendants, who 
were members of the army on May 27, 1960, and the defendants who entered politics in the DP received their share of these negative trials. However, especially in the second half of 1965, when the Justice Party, a supporter of the DP political line, came to power alone, the political pressures in the post-May 27 coup period were broken to some extent. Thus, after the Yassiada process, the defendants who served their sentences mostly in Kayseri and Adana prisons were released first. Then, the defendants of military origin overcame the grievances arising from their professional rights -such as military rank reinstatement, retired pay-, even if this occurred late. This article discusses the adventures of the defendants of military origin for the 1960 coup investigating the subject beginning with the start of the DP's rule in 1950 and ending with the rights offered to military personnel based on their ranks. 


\section{Giriş}

DP'nin tek başına iktidar olmasıyla birlikte askerî bürokratik kadrolar üzerinde etkin olmasının bir nedeni, özellikle 1940'ların ortalarından itibaren Soğuk Savaş'ın önemli bir kutbu haline gelecek olan ABD'ye eğitim amacıyla giden öğrenci ya da genç subayların profesyonel ordulardaki işleyişi görmeleri açısından yurt dışında aldıkları eğitimdi. Bu dönem öncesinde Türk ordusu, içine kapalıydı ve ordunun elindeki teknik ekipmanlar da eskiydi. 'İkinci Dünya Savaşı'nın sürdüğü 1940'lı yılların ortalarına kadar Türkiye'de, Mareşal Fevzi Çakmak ve onun yirmi yılı aşkın bir süredir genelkurmay başkanlığını yaptığı bir ordu vardı. Türkiye, savaş sürecinde ilk olarak Batı ittifakı tarafında yer alsa dahi bir denge politikasını önceliği haline getirdi. Fakat Almanya'nın bu dönemdeki amacı, Türkiye'nin kendi lehine savaşta yer alması için çabalamak oldu. Hatta söz konusu dönemde Almanya, Ankara Büyükelçisi von Papen aracıllı̆̆ ile Genelkurmay Başkanı Mareşal Fevzi Çakmak ve TSK'nın komuta kademesini bunun için etkilemeye çalıştıysa da, Türkiye, öncelikli amacı olan denge politikasını sürdürdü. Bu sürece paralel olarak ilk neden, bir kısım subayın kadrolarında bulundukları orduyu TSK'nın o dönemdeki teknik yetersizliklerinden dolayı farkl1, güçlü ordularla karşılaştırmasıyd.$^{2}$

İkinci Dünya Savaşı'nın bitimiyle birlikte BM'ye üye olundu ve bu politik yönelimin de etkisiyle çok partili sisteme geçilerek bir muhalefet partisi kuruldu. Dolayısıyla tek partili süreçte aslında muhalif olması muhtemel sağcı ya da muhafazakâr asker bürokratların önünde, CHP harici bir siyasi seçenek belirecekti. Örneğin Köy Enstitüleri çoğunlukla tek parti ideolojisini benimsemeyen, çoğunluğu Türk sağına mensup, o dönemde milliyetçi-muhafazakâr kesimler tarafından -komünizm karşıtllğı bağlamında- eleştirilerin odağında tutuluyordu. Enstitülerde TSK'nın hiyerarşik düzeni için gerekli olduğu yadsınamayacak ölçüde disiplinden ve itaat etme ya da sadık olma bilincinden yoksun bireyler yetiştirildiği savunuluyordu. ${ }^{3}$

1 Türk ordusundaki yetersizliklerin farkında olanlar sadece bir kısım ordu mensubu değildi. İkinci Dünya Savaşı'nda Türkiye'ye ekonomik yardımlar yapan İngiltere de bunu farkındaydı ve İngiltere, savaş sonrasında ekonomik durumu kötü olduğu için bu yardımların devam etmesini Amerika'dan isteyecekti. Amerika'nın “Truman Doktrini” çerçevesinde 1947 yılında Türkiye’ye yaptığı yardımları bu çerçevede değerlendirmek gerekir. Yeni ekonomik yardımların, dünyanın ABD ve SSCB olarak çift taraflı bir kutuplaşma ortamına dönüşeceği, Soğuk Savaş olarak adlandırılacak sürecin başladığı yıllarda gelecek olması da anlamılıd. Bu yardımlar, bir yandan ordunun modernizasyonunda kullanılırken diğer yandan Amerika da, SSCB'ye karşı Türkiye'nin jeopolitik konumundan yararlanacaktı. Doğan Akyaz'ın da belirttiği gibi ordunun ABD etkisindeki bu yeni yapılanması, 1952 yılında NATO’ya üye olunması ile sürecekti. Bkz. Doğan Akyaz, Askerî Müdahalelerin Orduya Etkisi: Hiyerarşi Dışı Örgütlenmeden Emir Komuta Zincirine, 3. bs., İstanbul, İletişim Yayınları, 2009, s. 43-56; Tamer Nalbant, Demokrat Parti Döneminde Ordu-İktidar ilişsileri, Ankara Üniversitesi, Türk İnkılap Tarihi Enstitüsü, Yayımlanmamış Doktora Tezi, 2019, s. 32; Feroz Ahmad, Modern Türkiye ’nin Oluşumu, 15. bs., çev. Yavuz Alogan, İstanbul, Kaynak Yayınları, 2016, s. 125.

2 Günay Göksu Özdoğan, "II. Dünya Savaşı Yıllarındaki Türk Alman İlişkilerinde İç ve Dış Politika Aracı Olarak PanTürkizm”, Türk Dış Politikasının Analizi, 3. bs., der. Faruk Sönmezoğlu, İstanbul, Der Yayınları, 2004, s. 135-144.

3 Asım Karaömerlioğlu, Orada Bir Köy Var Uzakta, 2. bs., İstanbul, İletişim Yayınları, 2011, s. 107. 
27 Mayıs Darbesi'nin cuntacılarından Albay Alparslan Türkeş de 1940’ların sonlarında Soğuk Savaş'ın güçlü kutbu Amerika'da eğitim almış subaylardandı. Türkeş, Millî Şef döneminde de ordu içinde cunta eğilimleri bulunduğundan ve o dönemde de Millî Şef İnönü’ye karşı darbe yapma hazırlıkları olduğundan bahsediyordu. Bu, o dönemdeki bazı asker bürokratların içindeki muhafazakâr eğilimin varlığına işaret ediyordu. $\mathrm{Bu}$ yüzden birçok ordu üyesinin CHP'den fikren kopmasının bir nedeni de ideolojikti. ${ }^{4}$

Öte yandan asker bürokratların CHP'den kopuşunda İkinci Dünya Savaşı dönemindeki Türk dış politikasının da etkili olduğu bir fikir olarak ortaya atılabilir. Ama bunun için dönemin Fevzi Çakmak liderliğindeki komuta kademesi ve hükûmeti arasında dış politikada anlaşmazlık vardı gibi bir ifade kullanmak mümkün değildir. Söz konusu dönemde ordu üst yönetimindeki bazı isimlerde Alman hayranlığının mevcut olabileceğini varsaysak bile İnönü ve onun hükûmetinde de Alman hayranlığı olan isimler vard1. Nitekim Başbakan Şükrü Saraçoğlu ya da Dışişleri Bakanı Numan Menemencioğlu bile bir yandan Alman hayranıyken diğer yandan Türkiye'nin savaşın dışında kalması taraftarıydılar. Öyle ki bu dönem, son kararları Cumhurbaşkanı İsmet İnönü’nün onayladı̆̆ı bir süreçti. ${ }^{5}$

Asker bürokratların CHP'den kopuşunun bundan çok daha net bir şekilde ortaya konduğu bir durum da söz konusu dönemde askerlerin oy kullanma haklarının bile olmamasıydı. Bu bağlamda 1942 yılında alınan bir karara göre subayların seçme ve seçilme haklarının olmadığı ifade ediliyordu. ${ }^{6}$ Buna ilaveten 1946 yılında çıkarılan Milletvekilleri Seçimi Kanunu'nda alınan bir karara göre de subaylar seçme hakkından yoksun birakılıyordu. ${ }^{7}$ Ayrıca genç subayların terfilerinin geciktirilmesi de onlarda CHP'ye karşı bir tepki yaratacaktı. ${ }^{8}$ Tüm bu gelişmelerin ve en önemlisi İkinci Dünya Savaşı sonrasında muhalefetin Türkiye'de canlanmasının; özellikle alt rütbeli subayların CHP'ye tepki duymasına neden olduğu ve bunun da emekli askerleri siyasete katılmaya sevk ettiği açıktır. Bu doğrultuda İkinci Dünya Savaşı'nın yaşandığı yıllardaki

4 Türkeş, bu dönemde biraz da abartılı bir şekilde genelleme yaparak ordu içindeki subayların Millî Şef İsmet İnönü’yü sevmediği iddiasındayken; bu dönemi toplumsal olarak "hastalık ve açlık", toplumun sahip olduğunu düşündüğü "manevi" değerler bağlamında ise "ahlâksızlık" dönemi olarak değerlendiriyordu. Alparslan Türkeş, 27 Mayls, 13 Kasım, 21 Mayıs ve Gerçekler, 2. bs., İstanbul, Dokuz Işık Yayınevi, 1977, s. 16-21.

5 William Hale, Türkiye'de Ordu ve Siyaset, çev. Ahmet Fethi, İstanbul, Alfa Yayınları, 2014, s. 122-123; Şevket Süreyya Aydemir, Ikinci Adam: 1938-1950, C.II, İstanbul, Remzi Kitabevi, 1968, s. 249-250.

6 Servet Armağan, "Türkiye'de Parlamento Seçimleri”, İstanbul Üniversitesi Hukuk Fakültesi Mecmuası, C.33, S.3-4, 1967, s. 76.

7 Milletvekilleri Seçimi Kanunu, 4918 sayılı kanun numarası ile 5 Haziran 1946 tarihinde kabul edilmişti. Bkz. Resmî Gazete, S.6326, 6.6.1946, s. 10701-10702.

8 Doğan Akyaz, Askerî Müdahalelerin ..., s. 62. 
Genelkurmay Başkanı Mareşal Fevzi Çakmak’ın tek partili siyasi düzenin bir muhalifi olarak siyasete atılması anlamlıdır. Bir diğer açıdan CHP'ye rakip bir siyasi partinin varlı̆̆1, kurucu kimliklerinin önemini isimlerinde/rütbelerinde taşıyan karizmatik üst düzey asker bürokratların da CHP, DP ve sonrasında MP arasında siyasi seçenek olma durumunu ortaya çıkardı. İlk aşamada CHP ve DP, asker bürokratları siyasi bir koz olarak kadrolarında bulundurma yoluna gitti. Bunun için de önce 1950-1960 yıllarındaki DP-ordu ilişkilerine, diğer yandan da MP'nin askerler için sonradan bir seçenek olarak belirmesine dikkat çekmek gerekir.

$\mathrm{Bu}$ dönemde CHP, İstanbul'a geldiğinde kendisini Haydarpaşa Garı'nda görkemli bir kalabalık karşılayan Mareşal Fevzi Çakmak'a beş defa milletvekili olma teklifinde bulunmuş ama Çakmak, DP'den bağımsız aday olma yolunu seçmişti. ${ }^{9}$ Çakmak, DP'den bağımsız milletvekili olduktan birkaç yıl sonra ise bu sefer tarafsızlığını bir yana bırakıp içlerinde yine eski bir general olan Sadık Aldoğan'ın da olduğu Millet Partisi’nin kurucuları arasında yer alacaktı. Mareşal Fevzi Çakmak ismi, halk tarafindan tanınırlığı açısından düşünülürse, bir siyasi partinin oy potansiyelini arttırıcı bir etkendi. Kısacası içinde emekli asker bürokratların da olduğu bu yeni partiyi oluşturan isimler, tek parti döneminde sağlanamayan özgürlük ortamının gerek DP'nin parti içi gerekse de DP politikaları bağlamında oluşturulamadığı düşüncesindeydi. ${ }^{10}$

1946 y1lı genel seçimlerinden sonra meclis başkanı olan siyasetçinin, CHP'nin adayı Kazım Karabekir olması tesadüf değildi. Nitekim bunun sonrasında yine CHP'den meclis başkanlığı yapan ve daha sonra DP saflarına katılacak olan Kurtuluş Savaşı Komutanı Orgeneral Ali Fuat Cebesoy da bir başka örnekti. ${ }^{11} \mathrm{Bu}$, Cumhuriyet kurulduktan sonra muhalefet ya da iktidar fark etmeden özellikle emekli asker bürokratların siyasi alandaki özgül ağırlığı açısından bir göstergedir. Bu durum hem DP'nin tek başına iktidar konumunu elde edeceği 14 Mayıs 1950 öncesinde hem de sonrasında devam edecekti.

9 Şevket Süreyya Aydemir, Íkinci Adam: 1938-1950..., s. 449; Feroz Ahmad-Bedia Turgay Ahmad, Türkiye'de Çok Partili Politikanın Açıklamalı Kronolojisi (1945-1971), Ankara, Bilgi Yayınevi, 1976, s. 22-23.

10 DP saflarından ayrılmak durumunda kalan “aşırı”lar; Sadık Aldoğan, Hikmet Bayur, Kenen Öner, Osman Bölükbaş1 gibi isimlerdi. Mareşal Fevzi Çakmak, yeni kurulan partinin "fahri başkanlığına” getirilirken Hikmet Bayur, partinin "genel başkan”' olacakt1. Bkz. Ahmet Gülen, Demokratikleşme Sürecinde Mareşal Fevzi Çakmak' in Siyasî Faaliyetleri (1946-1950), Ankara, Berikan Yayınevi, 2019, s. 77-82; Nahit Saçlığlu, Sadık Aldoğan: Bir Özgürlük Savaşçısı, İstanbul, Günlük Ticaret Tesisleri, 1990, s. 33-34.

11 Doğan Akyaz, Askerî Müdahalelerin ..., s. 58. 


\section{DP'nin Ordu Politikaları ve Bu Yönde Hareket Eden Asker Bürokratların 27 Mayıs 1960 Darbe Sürecine Etkileri}

Bir kısım asker bürokratı Yassıada' da yargılanacak konuma getiren gelişmelerin ilk aşaması, 1950 yılı genel seçimlerinde DP'nin ordunun yarısından fazlasının desteğini almasıyla başlamış oldu. Seçim sonuçlarının DP adına olumlu gelmesiyle birlikte artık ordu içindeki atamalar da DP Hükûmeti'nin inisiyatifinde; dolayısıyla 1950 yılı öncesindeki asker-bürokrat kadroların niteliğinin tersine olacaktı. ${ }^{12}$ Şevket Süreyya Aydemir'in de belirttiği gibi DP'nin bu dönemde orduda yapılması gereken reformlarla ilgili görüşlerini, eski bir ordu üyesi olan ve gelecekte DP'den; önce Ulaştırma, sonra Millî Savunma bakanlığı yapacak olan Em. Kurmay Albay Seyfi Kurtbek ortaya koymuş olmalıdır. Kurtbek'in askerî düşünce yapısı, orduyu militarist bir anlayışla ele alan fikirleri, ilk aşamada DP'li siyasi seçkinler tarafından olumlu karşılanmıştı. Aslında DP'li muktedirler, ordudaki teknik yetersizliklerin ve kadroların yaşlandığının farkındalardı. Aksayan ordu mekanizmasında, araç gereç bakımından bir ölçüde yenilikler yapılabilirdi. Ama DP'li muktedirlerin ordu ile ilgili görüşleri, onların zihnindeki Türk ordusu tahayyülü doğrultusunda şekillendiği üzere öncelikle askerler ve siviller arasındaki sınırların net bir şekilde belirlenmesiydi. Dolayısıyla Kurtbek'in öngördüğü düzenlemeler hiçbir zaman yapilmadi. ${ }^{13}$

Ayrıca DP tarafından askerî bürokratik kadrolarda değişiklikler yapmak amaçlanırken, sivil kadrolarda da değişikliklerin öngörüldüğü, bu yazının konusu olmasa da belirtilmelidir. Çünkü DP, uzun yıllar süren bir tek parti hâkimiyetine karşı toplumsal anlamda birçok kesimin teveccühüyle karşılaşmıştı ve doğal olarak bu da toplumun her kesiminden DP'ye destek geldiğini göstermişti. Konumuz açısından düşünürsek DP, ordudaki kadro dönüşümünü sağlamakla işe başladı. Bu doğrultuda bazı tasfiyelere gidildi.

Nitekim 1950 seçimlerinin üzerinden henüz bir ay bile geçmemişken genelkurmay başkanlığına Orgeneral Abdurrahman Nafiz Gürman'ın yerine, 1 Temmuz 1949 tarihinde kurulan Kara Kuvvetleri Komutanlığı'nın ilk komutanı Orgeneral Nuri Yamut getirildi. Bazı üst düzey komutanlarınsa ordu içindeki yerleri değiştirildi. Tabii bu yapılırken CHP'ye yakın asker bürokratlar yavaş yavaş pasif görevlere alınacak ve zamanla tasfiye

12 Tamer Nalbant, Demokrat Parti..., s. 34; Sitkı Ulay, "Harbiye Silah Başına!”: 27 Mayıs 1960, İstanbul, Kitapçılık Ticaret Limited Şirketi Yayınları, 1968, s. 14. DP Hükûmeti, 6 Haziran 1950 tarihinde ordunun komuta kademesinde tasfiyeye gitmiştir. Bunun en önemli nedeni, ordu içindeki bir hizbin CHP lehine darbe yapabileceği endişesiydi. İsmet İnönü’nün asker geçmişi ve karizmatik kişiliği, kuşkusuz DP'li muktedirleri bu konuda tedirgin ediyordu. Bu doğrultuda 16 general ve birkaç aylık süreye yayılarak 150 Albay, TSK'dan emekli edilmişti. Doğan Akyaz, Askerî Müdahalelerin..., s. 64-66.

13 Şevket Süreyya Aydemir, İkinci Adam: 1950-1964, C.III, İstanbul, Remzi Kitabevi, 1968, s. 48-54. 
edilecekti. ${ }^{14}$ Yine DP'nin 1954'te tek başına iktidar olduğu bir seçim sonrasında, DP'den milletvekili de olacak olan Orgeneral Nuri Yamut'un yerine bir süre sonra -ki arada Orgeneral Şükrü Kanatlı bu göreve vekâlet etmişti- 28 Mayıs 1954’te Orgeneral Nurettin Baransel atanacaktır. Bu atamaların hemen olmamasının önemli iki nedeninden biri hem DP Hükûmeti'nin genelkurmay başkanı seçme hususundaki ince eleyip sık dokuyan tavrı hem de komutanların rütbelerinin henüz en üst makama gelmeye yetmemesiydi. ${ }^{15}$

Orgeneral Baransel'in hükûmet tarafindan görev süresi dolmadan genelkurmay başkanlığından alınması da hükûmetin onunla uyuşmazlık yaşadığının bir belirtisiydi. Baransel'den sonra bir süre genelkurmay başkanı atanmadı. Daha sonra vekâleten evvela 10 Temmuz 1954'te Orgeneral Abdülkadir Seven atandı. Akabinde bir süre bu makam DP'li muktedirler tarafından boş bırakıldı ve hükûmet, 6 Haziran 1956' da bundan önce de kısa bir süre kara kuvvetleri komutanlığı yapmış olan ${ }^{16}$ İsmail Hakk1 Tunaboylu'yu genelkurmay başkanlığına atadı. ${ }^{17}$ DP Hükûmeti belli ki bu hususta risk almak istememiş; bunun yerine gerekirse makamı güvendiği bir komutana vekâleten vermeyi tercih etmişti. Bir memnuniyetsizlik halinde ise genelkurmay başkanı, görevinden ayrılmak zorunda bırakılabilirdi. Tabii ki bu -şayet mevcut başkanın kendi isteğiyle olan bir ayrılık değilse- tamamen hükûmetin ve genelkurmay başkanı atama konusuna özel önem verdiği bilinen Cumhurbaşkanı Celal Bayar'ın bir tasarrufuydu. Buna güzel bir örnek, 27 Mayıs Darbesi olduğu dönemdeki Genelkurmay Başkanı Mustafa Rüştü Erdelhun'un bu göreve atanma süreciydi.

Nitekim Orgeneral İsmail Hakkı Tunaboylu, 1957 yılının ekim ayında emekliliğini istedi ve bu görevden ayrıldı. Tunaboylu'nun ardından askerî hiyerarşik teamüllere göre en yakın kişiyse Orgeneral Necati Tacan'dı. Bu süreçte Millî Savunma Bakanlığı

14 Resmî Gazete, S.7527, 8.6.1950, s. 18597.

15 Yavuz Özgüldür, Orgeneral Mustafa Rüş̧ü Erdelhün: 27 Mayıs 'tan Yassıada'ya Siyasetçi-Asker Ekseninde İlginç Bir Portre, İstanbul, İkinci Adam Yayınları, 2018, s. 33.

16 Yavuz Özgüldür, Orgeneral..., s. 34-35.

$17 \mathrm{Bu}$ atama kararında ismi geçen ve General Nurettin Baransel'den sonra ordu üst yönetimine atanan dönemin bazı asker bürokratları, yazının aşağıdaki kısımlarında daha net görülebileceği gibi öncelikle 27 Mayıs Darbesi'ne gidiş sürecinde asker ya da DP'li siyasetçi olarak etkisi olan ve bu yüzden de Yassıada'da yargılanacak olan isimlerdi. Karar şöyleydi: "Erkânıharbiyei Umumiye Reisi Orgeneral Nurettin Baransel’in Yüksek Askerî Şûra Âzalığına, Kara Kuvvetleri Kumandanı Orgeneral İsmail Hakkı Tunaboylu’nun Erkânıharbiyei Umumiye Reisliğine, Birinci Ordu Müfettişi Orgeneral Nurettin Aknoz'un Kara Kuvvetleri Kumandanlı̆̆ına, Üçüncü Ordu Müfettişi Korgeneral Nazmi Ataç'ın Birinci Ordu Müfettişliğine, İkinci Ordu Müfettişi Korgeneral Necati Tacan'ın Üçüncü Ordu Müfettişliğine, Erkânıharbiyei Umumiye İkinci Reisi Korgeneral Rüştü Erdelhün'ün İkinci Ordu Müfettişliğine ve Yüksek Askerî Şûra Âzası Orgeneral Feyzi Mengüç’ün Askerî Temyiz Mahkemesi Reisliğine tâyinleri; Millî Müdafaa Vekâletinin 1/6/1956 tarihli ve 215/2641 sayıl yazlsı üzerine, 1631 sayll kanunun 40 incl ve 5398 sayıl kanunun 3 ve 4 üncü maddelerine tevfikan, icra vekilleri heyetince 1/6/1956 tarihinde kararlaştırılmıştır”. Bkz. Resmî Gazete, S.9327, 8.6.1956, s. 14507. 
tarafından Tacan'ın göreve atanması için ardı ardına çıkarılan kararnameler, Bayar tarafından üç defa veto edildi. Bir diğer deyişle Tacan, Cumhurbaşkanı Celal Bayar'ın genelkurmay başkanlığına atamak istediği Rüştü Erdelhun'dan daha kıdemli bir ordu mensubuydu. Fakat hükûmet bu atamayı yapmak yerine Orgeneral İbrahim Feyzi Mengüç'ü 11 Ekim 1957 tarihinde genelkurmay başkan vekili olarak görevlendirdi. Ta ki Orgeneral Necati Tacan 28 Temmuz 1958'de vefat edene kadar. ${ }^{18}$ Ayrıca belirtmek gerekir ki kara kuvvetleri kumandanı olduktan hemen sonra Necati Tacan'a, Kurmay Albay Sadi Koçaş'1n liderlerinden biri olduğu cuntacı grup tarafından DP'ye karşı yapılacak olası bir askerî darbenin lideri olması için teklif yapılmış ve bu teklif Tacan tarafindan kabul edilmiştir. Tacan'ın zamansız ölümü üzerine "Sadi Koçaş grubu”nun çabaları boşa gidecektir. Dolayısıyla Cumhurbaşkanı Celal Bayar, Necati Tacan’ı genelkurmay başkanlığına atamamakla büyük ihtimalle farkında olmayarak o dönem için isabetli bir karar vermiştir. ${ }^{19}$

Orgeneral Tacan, öldüğünde kara kuvvetleri komutanı; Orgeneral Rüştü Erdelhun ise ikinci ordu komutanı idi. Sonraki süreçte Erdelhun, kara kuvvetleri komutanı olarak atand1 ve ardından 23 Ağustos 1958'de artık genelkurmay başkanı olmasının önünde hiçbir engel kalmadi. ${ }^{20}$ DP Hükûmeti, iktidara geldiği ilk dönemde modern profesyonel orduların bir gerçeği halindeki ordu hiyerarşisine uygun davranıyordu. Şöyle ki yukarıda örneği verildiği gibi genelkurmay başkanı atanmadan önce aday ordu mensubu, bir süre için kara kuvvetleri komutanı yapılıyordu. Böylece hem komutanla çalışma şartları yakından izlenmiş oluyor hem de ordudaki hiyerarşik teamüllere uygun davranıliyordu. Tabii bu hiyerarşik tutumun ya da genelkurmay başkanlarının kara kuvvetleri komutanları arasından seçilmesinin sadece DP dönemine has bir durum olmadığını da belirtmek gerekir.

Rüştü Erdelhun'un göreve gelişs sürecinde, DP'li siyasi seçkinlerin bu tutumu değişti. Aslında hem Orgeneral Baransel'in hem de sonrasında Tunaboylu'nun atanmaları da doğrudan yapılmamıştı. Bu sefer farklı olan belki de Orgeneral Necati Tacan'ın göreve gelmesi hususunda Millî Savunma Bakanlığı'nın bununla ilgili önerisinin boşa çıkmasıyd1. Bu durum, DP 1950'de iktidara geldikten sonra yapılan bir atamadaki şu örnekten anlaşılabilir: “Genelkurmay Başkanlığına Kara Kuvvetleri Komutanı Nuri Yamut’un

18 Yavuz Özgüldür, Orgeneral ..., s. 36-37.

19 Abdi İpekçi-Ömer Sami Coşar, İhtilâlin İçyüzü, 2. bs., İstanbul, Türkiye İş Bankası Kültür Yayınları, 2012, s. 77-78. 27 Mayıs Darbesi'ne katılan bir tuğgeneral olan Sitkı Ulay, darbe yapılması ile ilgili konuları Orgeneral Tacan ile rahatça konuşabildiklerini anılarında belirtmektedir. Bu bağlamda Tacan'ın henüz kara kuvvetleri komutanı olduğu bir dönemde, kendisine sorulan bir soru üzerine ülkedeki gidişat1 değerlendirdiği şu sözleri önemlidir: "Bu gidişin sonu yoktur. Ordunun mutlak bir müdahalesi gerekir. Kara Kuvvetleri tamamdır. Siz Hava Kuvvetleri üzerinde de biraz çalışın. Ben Ankara'ya gidince herhalde bu işi yoluna koyarız”. Bkz. Sitkı Ulay, “Harbiye Silah Başına!,,..., s. 45.

20 Yavuz Özgüldür, Orgeneral..., s. 36-37. 
tâyini; Milli Savunma Bakanlığının 5/6/1950 ve 1581 sayıl yazısiyle yapılan teklifi üzerine 5398 sayll kanunun 3 üncü maddesine göre Bakanlar Kurulunun 5/6/1950 tarihli toplantısında kararlaştırılmıştır."21

Rüştü Erdelhun, henüz Konya'da ikinci ordu komutanı iken DP Hükûmeti ile yakından çalışma ve onu tanıma şansı buldu. Erdelhun ismi bu yüzden İçişleri Bakanı Namık Gedik, Dışişleri Bakanı Fatin Rüştü Zorlu ve özellikle Cumhurbaşkanı Celal Bayar için güvenilirdi. ${ }^{22}$ Ayrıca bu süreçte Erdelhun'un Başbakan Adnan Menderes ile de olumsuz bir ilişkisi yoktu. ${ }^{23}$ Nitekim Erdelhun, Dokuz Subay Olayı olarak bilinen, gerçekleşmeden açığa çıkan darbe girişiminden sonra Başbakan Adnan Menderes'e ikinci ordu komutanı sıfatıyla telgraf çekerek hükûmete olan bağlılıklarını ve desteklerini net bir şekilde ifade etmişti. Tanel Demirel'in de belirttiği gibi bu, Erdelhun'un genelkurmay başkanı olabilmesi için Adnan Menderes nezdinde akılda kalıcı iyi bir referans olarak kabul edilebilirdi. ${ }^{24}$ Dolayısıyla Erdelhun'un DP tarafindan genelkurmay başkanlığına atanmasının bir sebebi, DP'nin önde gelen muktedirlerinin desteğini almasıyken diğer yandan Orgeneral Tunaboylu istifa ettikten sonraki dönemin Millî Savunma bakanları Şemi Ergin ve Ethem Menderes'e güvensizlik de olabilir. Zaten bu güvensizlik, Yassıada yargılamaları sırasında ve sonrasında birçok eski DP'li tarafından da sıkça ifade edilmiştir.

Böylece Millî Savunma Bakanlığı'nın bu konuda boşa çıkan hamleleri, daha çok ordu içindeki askerlerin dikkatini olumsuz anlamda çekti. Bunun ne kadar doğru olduğu hususu farklı bir tartışmadır; ama belli ki DP, özellikle yakın coğrafyalarda (Mısır'da 1952'de, Suriye'de -Suriye'de sadece 1949-1954 yılları arasında 5 askerî darbe olmuştu- ve Irak'ta 1958 'de) gerçekleşen askerî darbelerin olumsuz etkilerinin farkındaydı. ${ }^{25}$ $\mathrm{Bu}$ yüzden Cumhurbaşkanı Celal Bayar ve hükûmet, olası bir darbe tehlikesine dikkat kesilmişti. Zaten bu, DP'nin ve özellikle Celal Bayar'ın 27 Mayıs Darbesi sürecine gidilirkenki otoriter tavırlarından da anlaşılacaktı.

21 Resmî Gazete, S.7527, 8.6.1950, s. 18597.

22 Adnan Çelikoğlu, Bir Darbeci Subayın Anıları: 27 Mayıs Öncesi ve Sonrası, 2. bs., haz. Ergin Konuksever, İstanbul, Yap1 Kredi Yayınları, 2017, s. 127. DP’nin bu doğrultuda yaptığı önemli bir icraat de Genelkurmay Başkanı Rüştü Erdelhun'un yaş haddinden emekli olması gerekirken bir kanun değişikliğiyle birlikte 27 Mayıs 1960 Darbesi'ne kadar görevde kalacak olmasıydı. Tabii bu da Genelkurmay Başkanı'nın ordu içindeki muhaliflerinin tepkisini çekecek bir hamleydi. Detaylı bilgi için bkz. Tamer Nalbant, Demokrat Parti.., s. 155. Resmî Gazete, S.10231, 15.6.1959, s. 21917.

23 Yavuz Özgüldür, Orgeneral ..., s. 54.

24 Tanel Demirel, "Demokrat Parti İktidarı ve Ordu”, Türkiye’nin 1950’li Yılları, 2. bs., haz. Mete Kaan Kaynar, İstanbul, İletişim Yayınları, 2016, s. 281.

25 Morris Janowitz, Military Institutions and Coercion in the Developing Nations, Chicago and London, The University of Chicago Press, 1977, s. 53. 
DP, siyasi kararların uygulayıcısı konumunda bir parti olarak siyasi gelişmelerle arasına mesafe koyan bir ordu modeli tahayyül etmiştir. Ayrıca bu, Cumhuriyet tarihinde hem ilk hem de DP'ye özgü bir durum değildi. CHP hükûmetleri, çok partili hayata geçildikten DP tek başına iktidar olana kadar geçen sürede Orgeneral Salih Omurtak ya da Orgeneral A. Nafiz Gürman gibi kendi siyasi çizgilerine yakın gördüğü isimleri genelkurmay başkanlığına atadı. Dolayısıyla DP yöneticileri, çalışmak istedikleri generalleri aslında CHP'nin geçmişte yaptığından farksız bir biçimde seçecekti. Zaten tek parti döneminde, ordudaki kadro değişikliklerinde Milli Şef İsmet İnönü gibi eski, saygın bir asker bürokratın kararları esastı ve dolayısıyla dönemin ordu üst yönetiminden tek parti yönetimi politikalarına büyük çapta bir tepki de gösterilemezdi. Çok partili sisteme geçildikten sonra bu durum değişecek, ordu üst yönetimindeki bazı isimlerden yer yer muhalif sesler de yükselecektir. Nitekim Atatürk döneminden beri ordunun siyasete karışmama geleneği devam etmiştir. DP dönemi değerlendirildiğinde bu, ordu üst yönetiminin de özellikle 1950'lerin sonlarından 1960'lara kadar sürecek siyasi kutuplaşmanın bir tarafı gibi görünmesini sağlamıştır. Örneğin 27 Mayıs Darbesi'nin cuntacı subayları, süreçteki davranışlarını hükûmetin yanında yer alan generallere karşı DP döneminde ilan edilen sıkıyönetim uygulamalarından bahsederek meşrulaştırmaya çalışmışlardır.

Nitekim Zafer Üskül'ün “olağandışı yönetim biçimi” olarak tanımladığı sıkıyönetim; hükûmetin yatıştırmakta zorluk çektiği ya da çekebileceği hadiselerde, kolluk kuvvetleri tarafından zor kullanılırken vatandaşların sahip olduğu hakların kolluk kuvvetleri lehine -orantısız güç kullanarak- aşındırılması ve bunun sonucunda olayların hükûmetin istediği doğrultuda bastırılması, bu vesileyle de gerekli önemlerin alınması gibi durumları içermektedir. ${ }^{26}$ Örneğin 1955 yılının 6-7 Eylül'ündeki gelişmeler bu niteliğe uygundu. DP Hükûmeti bu dönemde, İstanbul sıkıyönetim komutanı olarak -gelecekte Yassıada' da yargılanacak olan- Orgeneral Nurettin Aknoz'u tayin etti. Aknoz, yetkisini orantısız biçimde kullandı. 6-7 Eylül Olaylarından içlerinde Kemal Tahir, Aziz Nesin, Vedat Türkali gibi sol kesimden aydınların da olduğu isimleri sorumlu tuttu ve onları "salkım salkım" asmaktan bahsetti. Fakat Aknoz’un aydınlar hakkındaki iddiaları kanıtlanamadi. Ayrıca yasalara göre kendi alanı sadece İstanbul olmasına rağmen Ankara ya da İzmir'le ilgili uygulamalara da müdahale etti. Bu dönemde İzmir'de Sabah Postasl, Ankara'da Ulus, İstanbul'da ise Hürriyet, Tercüman ve birkaç gazete daha kapatıldı. ${ }^{27}$ Bunlardan Ulus gazetesi sınırsız,

26 Zafer Üskül, Siyaset ve Asker: Cumhuriyet Döneminde Sıkıyönetim Uygulamaları, 2. bs., Ankara, İmge Kitabevi, 1997 , s. 28.

27 Zafer Üskül, Siyaset ve Asker..., s. 130-135. DP'nin dört kurucusundan biri Fuat Köprülü başta olmak üzere DP Hükûmeti, 6-7 Eylül Olaylarının "komünistler”e mal edilmesi gerektiği fikrindeydi. Bkz. Altan Öymen, ... Ve İhtilal, 6. bs., İstanbul, Doğan Kitap, 2014, s. 121-125. 
Hürriyet ve Tercüman gazeteleri de 15 'er gün kapatıld1. Burada biraz da dikkat çekici olan, kurucu meclis üyeliği de yapan gazeteci Altan Öymen'in vurguladığg gibi Aknoz tarafından yayımlatılan bildiride geçen bazı söylemlerdi. Aknoz, gazeteler için "neşirden men ettim", "müddetsiz olarak men ettim" gibi 'dediğim dedik' bir tavırdaydı. Bu gücü de Yassıada'da birlikte yargılanacağı birçok DP'li muktedirden almıştı. ${ }^{28}$ Oysa Aknoz, daha sonra Yassıada'da yaptığı savunmada “Ancak 15 günlük bir tahkikatın neticesinde, hâdiselerin, komünistler tarafından yapılmadığını öğrendik. Bunun üzerine Kıbrıs Türktür Cemiyetinin tahriki sonunda mitinglerin tertip edilmek istendiğini, onların da gençliği galeyana getirdiği neticesine vardık'29 diyerek 6-7 Eylül Olayları sırasındaki tutumunun yanlışlı̆̆ını ortaya koymuştur.

Fakat bunların tersine Orgeneral Aknoz'un olumlu uygulamaları da olmuştu. Buna göre Aknoz, olayların 6 Eylül 1955 akşamı devam etmesi üzerine hem İçişleri Bakanı Namık Gedik’ten hem de Başbakan Adnan Menderes’ten çok kesin bir şekilde olayların ne pahasına olursa olsun yatıştırılması, eğer bu yapılamazsa da halka karşı silah kullanılması gerektiği yönünde bir emir almıştır. Orgeneral Aknoz, bu emirleri almasına rağmen nöbetçi amirine "Silâh kullanma emri aldım, fakat siz idare edin" diyerek olayların karşısında makul bir tutum gösterecektir. Şevket Süreyya Aydemir'e göre halkın üzerine ateş açılmadıysa, olaylar daha da tatsız bir hal almadıysa bunda en büyük pay Aknoz'undu. ${ }^{30}$ Şunu da göz önünde bulundurmak gerekir ki Aknoz, orgeneralliğe 1955 yılında getirilecek ve 6-7 Eylül Olaylarının ardından da birinci ordu komutanı olacaktı. Aknoz, bu görevinde Boğazların ve Trakya'nın güvenliğinden sorumlu ordu mensubuydu. Ardından da kara kuvvetleri komutanlığı görevine getirildi. Yukarıda bahsi edilen askerî hiyerarşi düşünüldüğünde, bir sonraki basamağı genelkurmay başkanlığına yükselmek olan bir generalin sorumluluk bölgesindeki icraatlarında kendinden emin tavırlar sergilemesinin nedeni bu olabilir.

Aslında ordudaki generallerin DP'nin sivil siyaset sınırları içindeki çizgiyi aşmamaları adına yaptıkları uygulamalar, modern orduların işleyişi açısından olumsuz bir gelişme değildi. Ama bir yandan -iktidar ve muhalefet olmak üzere- iki eğilim arasındaki siyasi kutuplaşma artarken diğer yandan buna benzer bir kutuplaşma, ordu içindeki fikren bölünme eğilimini de arttırdı. Bu dönemde cuntacılık faaliyetlerinde bulunan ordu üyelerinin TSK üst yönetimi karşısında konumlanmasının ana nedeni, Genelkurmay Başkanı Rüştü Erdelhun'un ve onun TSK'nın lideri olarak tutumunun

28 Altan Öymen, ... Ve Ihtilal, s. 139-140.

29 “Tanıklardan Orgeneral Nurettin Aknoz 'Mevkufiyetimin sebebi mebusluktan' dedi”, Yeni İstanbul, 22.10.1960, s. 1, 5.

30 Şevket Süreyya Aydemir, İkinci Adam: 1950-1964 ..., s. 184-186. 
beğenilmemesiydi. Zaten cuntacılık faaliyetleri, siyasi gelişmelere paralel olarak DP döneminde artmıştı. Ama belli ki faaliyetlerin 1960 yılına doğru fazlalaşmasının bir nedeni de ordu içindeki keskin Erdelhun karşıtlığıydı. Bu bağlamda, 27 Mayıs Darbesi'nin daha çok alt rütbeli subaylar tarafından yapılmasına şaşmamak gerekti. Ama bu, cuntacı askerlerin politik bir hedeflerinin olmadığ 1 anlamına gelmemelidir. Bu bağlamda tabii ki hoşlanılmayan ana unsur hem DP Hükûmeti hem de dolaylı olarak mevcut genelkurmay başkanıdır. Dolayısıyla cuntacıların hedefi hem politik hem de askerîdir. Ayrıca darbe sonrasında ne yapılacağına dair cuntacıların -MBK'nın bölünmesiyle yurtdışına gönderilen 14'lerden biri olan Alparslan Türkeş haricinde- herhangi bir hazırlık içinde olmadıkları da belirtilmelidir.

27 Mayıs 1960 Darbesi öncesinde özellikle siyasi kutuplaşmanın yarattı̆̆ı muhaliflerin yanında aydınlar, kentli tüccarlar, sivil bürokratlar ve ele alınan çalışmanın ana aktörü olan asker bürokratlar da yer aldı. Burada DP Hükûmeti'ni tek başına iktidara getiren tarihsel sosyolojik dinamiklerden biraz bahsetmek, 27 Mayss Darbesi'nin zihinlerde daha iyi konumlandırılmasını sağlayabilir. Bu bağlamda Tanzimat dönemi sonrasında elitist-jakoben kesimin rolü, buna karşı DP ile nelerin değiştiğine değinmek gerekir.

DP, kırsalda örgütlenmesini iyi kurmuş; birçok yerde doğru insanları il-ilçe örgütlerinin başına getirerek halkın istekleri, düşünceleri konusunda bilgi sahibi olmuştur. $\mathrm{Bu}$ liderler, orta sınıfı oluşturan kesimlerdi ve genelde küçük kentlerde yaşasalar da taşradaki koşulların zorluğunun farkındalardı. Sonuç olarak kırsal kesimin ihtiyaçlarını anlayabilmek, kırsalın desteğini -genel olarak- DP’ye getirmiştir. Köylü kesim, DP ile birlikte kendi gücünün farkına varmış, ${ }^{31}$ DP'nin kırsal kesime sunduğu olanaklar ise köylüye yeni bir statü sağlamıştı. Mesela Kırşehirli birkaç köylüyle 1957 yılında yapılan bir mülakatta bu köylülerin en çok yakındığı konu, tek parti döneminde olup da DP döneminde olmayan jandarma baskısıdır. Jandarma artık köylüleri dövmüyor, onların ürünlerine el koymuyor hatta hükûmet onlara tohumluk ürünler bile dağıtıyordu. Tek parti yönetiminin özellikle İkinci Dünya Savaşı yıllarında köylünün ürünlerine el koyması belli ki köylüde bir travma yaratmıştı ve kırsal kesimi de büyük oranda etkileyen bu yük, DP döneminde hafifleyecekti. ${ }^{32}$

Gülten Kazgan'a göre 1950’lerin tarım politikaları ile aslında bir dönüşüm gerçekleşti ve yeni bir üretim tarzı oluştu. Tek parti dönemindeki köylünün yerine artık küçük üretim yapan kesimler ortaya çıktı ve bunlar "aile işletmeleri”ni kurdular. Bu kesim,

31 Kemal H. Karpat, Türk Siyasi Tarihi, İstanbul, Timaş Yayınları, 2015, s. 100.

32 Kemal H. Karpat, Türk Siyasi..., s. 96. 
oylarını çoğunlukla DP’ye verecekti. ${ }^{33}$ Dönemin kırsal yapısı ve onun dönüşümünü sağlayan birçok etkenden bahsedilebilir. Mesela bunlardan biri, tarımda makineleşmenin önünün DP döneminde açılmasıdır. Ayrıca makineleşmeyle birlikte işçi gereksiniminin azaldığı yerler olmakla birlikte tarlada çalışan kişi, artık iş bulamaz ve şehre gider; şehirdeyse iş bulma imkânı DP dönemi öncesine göre yüksektir. Aslında birbirine bağlı bu etkenler, toplumsal değişim ve dönüşümün göstergeleridir.

Toplumsal değişime vurgu yapabilmek için yeni oluşan bir grup olan orta sınıfi da kısaca ele almak gerekir. Kemal Karpat' 1n da belirttiği gibi "üst tarımsal gruplar”, parti içinde egemen hale gelecek; sonra da bu üstünlüğü partideki "girişimci grup ve profesyoneller" ele geçirecekti. ${ }^{34}$ İktidarla birlikte üstünlüğü ele alacak olan "yeni burjuvazi"; eski devletçi burjuvaziye, bürokratlara ve aydın sınıflara karşı güvensizdir. Dolayısıyla da bu grupları etkisiz hale getirmek için önlemler almıştır. Mesela Halkevleri ve Köy Enstitüleri gibi kurumlar kapatılmıştır. İktidarın koyduğu yeni vergi sistemi, en çok kamu hizmetlerinde bulunan ücretli kesimin sırtında yük olmuştur. Sonuç olarak bu kesimlerin sosyal statüleri eskisine oranla düşmüştür. Bir aydın ya da bir subay, toplumda statüsü düşen bu gruba mensup kişilerdi. ${ }^{35}$ Örneğin askerlik mesleğinin prestiji DP döneminde düşmeye başladı. Subaylar da artık hem ekonomik zorluklarla karşı karşıya kalacaklar hem de kolay kolay kız verilmeyen kişiler haline geleceklerdi. ${ }^{36}$

Erken dönem cumhuriyet ya da tek parti dönemindeki asker-sivil bürokratik grup artık yerini yeni orta sınıflara bırakmıştır. Dolayısıyla DP döneminin olumsuz etkilerini yaşayacak olan da asker-sivil bürokrasi, bir diğer anlamda kentli sınıf olacaktır. Zaten aydınların dile getireceği ve DP'ye yönelteceği tepkiler de bu yüzdendir. DP döneminde sosyal statülerdeki değişim ve dönüşüm, bir kesimin ekonomik, siyasi ve benzeri alanlarda daha fazla etkin olmasını sağlamıştır. İncelenmesi gereken konularından birisi de aydınların DP ve öncesi DP dönemdeki tutumlarının ne olduğudur.

Kemal Karpat, yetişmeleri bağlamında aydınların iki gruba ayrıldıklarını belirtmiştir. Bunlardan bir tanesi Osmanlı döneminde yetişen aydınlar olup; bunlar daha çok o devrin anlayışına uygun, tüm düşüncelerini Osmanlı Devleti'nin parçalanmaması konusu üzerinden ortaya koymuş fakat amaçlarına ulaşamamış kişilerdi. Cumhuriyet dönemi aydınları ise daha çok aklı kullanmayı ön plana alan, pozitivizmi benimseyen kişilerdi.

33 Gülten Kazgan, “İzzettin Önder, Ergün Kip ve Çağlar Keyder’in Tebliğlerine İlişkin Yorum”, Türkiye’de Tarımsal Yapılar, der. Şevket Pamuk, Zafer Toprak, Ankara, Yurt Yayınları, 1988, s. 175.

34 Kemal H. Karpat, Kimlik ve İdeoloji, İstanbul, Timaş Yayınları, 2017, s. 197.

35 Kemal H. Karpat, Kimlik..., s. 122.

36 Kemal H. Karpat, Asker ve Siyaset, İstanbul, Timaş Yayınları, 2015, s. 320-321. 
Oysa bu, yetiştikleri çevreden -gelenek, din ve benzeri açılardan- farklı bir düşünce yapısıydı ve sonuçta aydınlar toplumsal anlamdaki düşüncelerle uyuşamadılar. Ayrıca aydınlar genelde devlet memuruydu. Böylece hem fikirlerini ifade ederken kısıtlanıyor hem de kendilerini devletin temsilcileri gibi görme alışkanlığ 1 kazanıyorlardı. ${ }^{37}$ Sonuç olarak toplumsal anlamda bir çözüm getirmek yerine kendi siyasi düşüncelerini gerçekleştirmek isteyen bir aydın grubunun varlığı ortadadır. Bu durumun da hem orduda hem de bürokraside, aydınların topluma yabancılaşması ve devletle bütünleşmesi gibi bir durumu ortaya çıkardı̆̆ 1 ifade edilebilir.

DP, iktidar olduğu 1950 genel seçimlerinden 27 Mayıs 1960 Darbesi’ne kadar girdiği tüm genel seçimlerden iktidar partisi olarak çıkacaktır. DP siyasetinin yönü, kazanılan 1954 seçimlerinden sonra askerî darbeye kadar olan süreçte değişecektir. Bu düşünceyle Tanel Demirel'in o dönemde DP milletvekili olan Samet Ağaoğlu'ndan aktardığı şu sözler arasında paralellik kurmak yerindedir: "Menderes'in kişiliğinde Başvekilliği süresince değişiklikler olmadı değil. 1954'e kadar başka idi, 1954 seçimleri bittiği gün yeni bir devri başladı." ${ }_{38} \mathrm{Bu}$ durum, DP'nin politikalarına da yansıyacak; 1950'lerin ikinci yarısında ortaya daha güç kaybetmeye başladıkça daha sert politikalar izleyen bir DP çıkacaktır. DP'nin son dönemi muhalefet tarafından en çok yıpratıldığı dönemdir.

Parti, 1957 seçimlerini kazansa da bir hayli güç kaybetmiş ve CHP'nin başı çektiği muhalefet, iktidar üzerindeki baskılarını arttırmıştı. Nitekim Vatan Cephesi'nin ya da Tahkikat Komisyonu'nun kurulması, muhalefet lideri İsmet İnönü ve CHP üzerinde artan bu baskılarla basın sansürü gibi birçok konuda eleştirilen bir DP vard1. Ayrıca bask1 sadece CHP ve diğer muhalefet partilerine yönelik değildi. Muhalif olan diğer toplumsal kesimler de bu baskıdan etkilenmeye başladı. Zaten sürecin cuntacılar tarafından bir darbeyle sonlandırılması, askerlerin bu baskıları görmelerindendi. Bu süreçte özellikle üniversite gençliğinin ön planda olduğu gösteriler yapıldı ve gösterilerdeki ordu-gençlik el ele sloganları, hareketlenmelere önemli bir temel oluşturdu. ${ }^{39} 1960$ yılının 28-29 Nisan'ında İstanbul ve daha sonra Ankara'daki gençlik gösterileri, bu dönemdeki bazı ordu üyelerinin tutum ve davranışlarını ortaya koymak açısından önemli gelişmelerdi.

Aslında Tahkikat Komisyonu'nun resmî nitelik kazanmasıyla birlikte muhalefet üzerindeki baskının daha da artacağı kesinleşmişti. Fakat komisyonun kurulması, muhalif

37 Kemal H. Karpat, Türk Demokrasi Tarihi, İstanbul, Timaş Yayınları, 2016, s. 216-217; Metin Heper, Türkiye'de Devlet Geleneği, 5. bs., çev. Nalan Soyarık, İstanbul, Doğu Batı Yayınları, 2015, s. 120-144.

38 Tanel Demirel, Türkiye’nin Uzun On Yıll, İstanbul, Bilgi Üniversitesi Yayınları, 2016, s. 249.

39 Gökhan Atılgan, “Tarımsal Kapitalizmin Sancağı Altında”, Osmanlı'dan Günümüze Türkiye'de Siyasal Hayat, 3. bs., haz. Gökhan Atılgan, Cenk Saraçoğlu, Ateş Uslu, İstanbul, Yordam Kitap, 2019, s. 449-473. 
basının ve hukukçu akademisyenlerin komisyonun anayasaya aykırı taraflardan bahsetmesine engel olmadı. Siyaseten de bu kutuplaşmanın sürmesi, öğrencileri sokağa döken nedenlerdendi. Olaylar İstanbul Üniversitesi Beyazıt Kampüsü’nde başladı ve polis, olaylara müdahale etti. Turan Emeksiz adında bir öğrencinin hayatını kaybettiği protestolarda gençler, hükûmetin istifasını istediler. Sonradan askerler de olaylara dahil oldu ve polislerin tersine göstericiler tarafından iyi karşılandılar. Bu sırada İstanbul Üniversitesi Rektörü Sıddık Sami Onar da öğrenciler gibi polisin sert tutumundan nasibini aldı. Üniversite dışında tedavi edildikten sonra tekrar üniversite kampüsüne gelen Onar'ın başı sarılı halde konuşmasının da tesiriyle durma noktasına gelen olaylar, öğrencilerin bu kez Beyazıt Meydanı'nda toplanmalarıyla devam edecekti. Böylece 28 Nisan 1960 günü öğleden sonra sıkıyönetim ilan edildi. ${ }^{40}$ İstanbul'da sıkıyönetimin başına Orgeneral Fahri Özdilek getirildi. 27 Mayıs sonrasında cuntacıların cephesine geçecek olan Özdilek, gazeteciler Abdi İpekçi ve Ömer Sami Coşar'ın da belirttiği gibi DP Hükûmeti'nin tavırlarına muhalifti ama herhangi bir cuntanın üyesi de değildi. Özdilek'e göre sorunların uzlaşma ve sükunetle çözülmesi daha yerinde bir tavırdı. Genelkurmay Başkanı Rüştü Erdelhun tarafından bu göreve atanan Özdilek, o sırada birinci ordu komutanı olmasıyla da hükûmet için o günkü şartlarda bu göreve en uygun isimdi. ${ }^{41}$

İstanbul olaylarında kendisinden tutumunu sertleştirmesini isteyen, bizzat Cumhurbaşkanı Celal Bayar ve daha çok Bayar'ın yönlendirdiği isim olan Genelkurmay Başkanı Rüştü Erdelhun'du. Aynı zamanda DP'lilerin düşüncelerine son derece itimat ettiği Prof. Ali Fuat Başgil'in de bu süreçle ilgili görüşleri, 30 Nisan 1960 tarihinde kendisiyle yapılan bir toplantıda alınmış; fakat önce Cumhurbaşkanı Bayar sonra da Başbakan Adnan Menderes, Başgil tarafından kendilerine iletilen olaylar karşısında ölçülü davranma önerilerini dikkate almamışlardır. Başgil'in DP'li siyasi seçkinlere göstericiler karşısında makul olmalarını önermeleri karşısında Bayar: "Tam aksine, son derece sert davranılması ve kışkırtıcıların herkesin ders alacă̆ bir şekilde cezalandırılması lâzım" demiştir. ${ }^{42}$

Diğger yandan Erdelhun'a İstanbul'da yakın olan komutan, hükûmetten aldığı emirleri harfiyen uyguladığı için Akis dergisinde kendisinden "telefon paşası" olarak

40 Kendisi de İstanbul Üniversitesi’nde öğretim üyesi olan Ali Fuat Başgil, olayların canlı tanı̆̆ıydı. Bkz. Ali Fuat Başgil, 27 Mayıs İhtilali ve Sebepleri, 6. bs., çev. Cemal Aydın, İstanbul, Yağmur Yayınları, 2014, s. 119-123. Ayrıca şunu da belirtmek gerekir ki, sıkıyönetim sürecinde hükûmetin yanında orduya nazaran belki daha doğrudan hükûmetin destekçisi olabilecek emniyet görevlileri ve valiler de olaylara önemli etkilerde bulunuyordu. Abdi İpekçi-Ömer Sami Coşar, İhtilâlin..., s. 105-107.

41 Adnan Çelikoğlu, Bir Darbeci Subayın ..., s. 115-116; Abdi İpekçi-Ömer Sami Coşar, İhtilâlin ..., s. 165.

42 Bkz. Ali Fuat Başgil, 27 Mayıs İhtilali ve Sebepleri..., s. 124-130. 
bahsedilen İstanbul Merkez Komutanı Tümgeneral Kemal Binatlı idi. Binatlı, İstanbul Sıkıyönetim Komutanı Fahri Özdilek'in İstanbul'da söz geçiremediği bir generaldi. Nitekim protestolar sırasında toplanıp Davutpaşa Kışlası'na götürülen göstericiler, sertlik yanlısı olmayan askerler tarafından yolda bırakılsalar da Emniyet Müdürlüğ̈üne götürülen bir kısım öğrenciye kötü davranılmıştı ve İstanbul Merkez Komutanı Kemal Binatlı da bunun sorumlularından biri olarak görülüyordu. ${ }^{43}$ Genelkurmay Başkanı Erdelhun da Yassıada'daki savunmasında, Davutpaşa'ya götürülecek öğrencilerin ikna edilerek oraya götürüldüklerini; bunlardan erkek olanların Davutpaşa’ya götürülürken kızların özel arabayla evlerine bırakıldıklarını, evleri olmayan kızların ise orduevinde misafir edildiklerini söyleyecekti. ${ }^{44}$

İstanbul Sıkıyönetim Komutanı Orgeneral Özdilek göreve geldikten sonra yayımlanan bildiri ise toplantı yasakları, dışarı çıkma yasağı, olaylarla ilgili fotoğrafların basın tarafından kullanılmaması gerektiği gibi yasakları içeriyordu. Fakat Özdilek'in bu çabalarını yetersiz gören Cumhurbaşkanı Bayar, Erdelhun'u İstanbul'a gönderecek ve ondan protestoculara gösterilen tavrın sertleştirilmesini isteyecekti. Erdelhun, olayları helikopterle yukarıdan takip etti ve gerekirse göstericilere ateş açılmasını -MBK üyelerinden Ahmet Yıldız'ın Fahri Özdilek’ten aktardığı kadarıyla Bayar, "hedef gözetmeden ateş" mesajını Özdilek'e de iletmişti- emretti ve bunu küçük notlar halinde yazıp helikopterden aşağıya attı. ${ }^{45}$ İstanbul'daki olaylar 29 Nisan 1960 tarihinde Ankara'ya da siçradi. Bu kez öğrenci olaylarının adresi Ankara Üniversitesi'nin birçok fakültesiydi ama olaylar ağırlıklı olarak hukuk ve siyasal bilgiler fakültelerinde gerçekleştikten ${ }^{46}$ sonra Kızılay Meydanı'na sıçradı. ${ }^{47}$

Ankara'daki olaylar için atanan Sıkıyönetim Komutanı Erdelhun'un kendisine ve hükûmete yakınlığı konusunda Özdilek'ten daha çok güvendiği isim, Kore'deki Türk tugayının komutasını da üstlenmiş olan General Namık Argüç’tü. Argüç, olayların başından itibaren net bir hamle yapmak niyetindeydi. Bu yüzden de göstericiler arasında

43 Adnan Çelikoğlu, Bir Darbeci Subayın..., s. 117; "Yassıada Duruşmaları”, Akis, 6.2.1961, s. 10. Emniyet görevlileri de bu süreçte Bayar'ın "hedef gözetmeden ateş” mesajını uyguluyordu. Muhtemelen birçok göstericinin olaylarda hayatını kaybetmesinde ve yaralanmasında bu tutumun büyük etkisi vardı. Bkz. Ahmet Yıldı, İhtilalin Iç̧inden: Anılar, Değerlendirmeler, İstanbul, Alan Yayıncılık, 2001, s. 125.

44 Fatih Uğur-Mustafa Gürlek, 50 Yıllık Sır: Genelkurmay Başkanı Erdelhun'un 27 Mayıs Cuntasını Deşifre Eden Günlükleri, İstanbul, Zaman Kitap, 2012, s. 256

45 “İstanbul ve Ankara'da örfi idare”, Yeni İstanbul, 29.4.1960, s. 1, 5; Altan Öymen, ... Ve İhtilal, s. 676. Helikopterden aşağıya atılan notlar, Genelkurmay Başkanı'nın Yassıada'daki yargılama sürecinde dava konusu edildi. Erdelhun'un 30 Nisan 1960 tarihinde İstanbul'daki helikopter uçuşuyla ilgili Yassıada'daki savunması için bkz. Fatih Uğur-Mustafa Gürlek, 50 Yillık Sir..., s. 256-258.

46 Altan Öymen, ... Ve İhtilal, s. 679.

47 Şevket Süreyya Aydemir, Ikinci Adam: 1950-1964 ..., s. 409. 
gruplaşmaların olmasını engelleme hususunda titiz olacaklarını, tersine bir durumda ateş açmaktan çekinilmeyeceğini belirtti ve 29 Nisan 1960 günü Ankara Üniversitesi Siyasal Bilgiler Fakültesi’ndeki birçok yere ateş açtırarak dediğini yaptı. Ardından emniyet kuvvetlerinin atlı birlikleri okul içlerine kadar girerek göstericilerin üzerine sürüldü. ${ }^{48}$ Öyle ki Cumhurbaşkanı Bayar, olaylara karşı gösterdiği sert tutumdan dolayı Namık Argüç'ü özel olarak kutlamıştı. Genelkurmay Başkanı Erdelhun ise İstanbul'da hala devam eden olaylarda Namık Argüç’le aynı tavrı göstermeyen Tugay Komutanı Refik Tulga'yı -ki Tulga, 27 Mayıs sonrasında İstanbul Valisi ve Belediye Başkanı yapılacaktı- azarlayacaktı. ${ }^{49}$ Ayrıca bu durum, ordu içinde olaylara müdahale eden askerlerdeki görüş farklılığını da daha net bir şekilde açığa çıkarmıştı. Nitekim Ankara Sıkıyönetim Komutanı Argüç'ün ateş açma emrini uygulamayan ordu üyeleri de vardı. Mesela 27 Mayıs sonrasının MBK üyelerinden olup olaylar sırasında binbaşı olan Vehbi Ersü, Ankara Sıkıyönetim Komutanı Argüç’ü yanıltmayı tercih etmiş ve onun ateş emrini dinlememişti. Ersü, bayılma numarası yaptıktan sonra hastaneye kaldırıldı. Vehbi Ersü'den sonra Yüzbaşı Fethi Gürcan da bu emri dinlemedi ve Sıkıyönetim Komutanı Argüç'le tartışarak ateş emrinin durmasını sağladı. ${ }^{50}$

Bu sırada sıkıyönetim devam etmekteydi. Fakat bu durum, 5 Mayıs 1960 tarihinde hükûmete karşı bir gösteri daha düzenlenmesini engellemeyecekti. Üstelik bu sefer DP'li siyasi seçkinler sahaya inecek ve göstericilerden sert tepkiler alacaklard1. ${ }^{51}$ Oysa DP'li muktedirlerin bu uzlaşmaz tutumu, ülkeyi 27 Mayıs Darbesi'ne götüren en önemli gelişmelerdendi. Bu konuda son uyarı, 21 Mayıs 1960’ta Kara Harp Okulu öğrencilerinin hükûmeti protesto etmek amacıyla yaptığı yürüyüştü. 27 Mayısçı bir cuntacı olan Orhan Erkanlı’ya göre yürüyüş için öğrencilere herhangi bir emir verilmemişti ve yürüyüşün cunta oluşumlarıyla bir ilgisi yoktu. Fakat Kızılay’da buluşup yürüyüşü yapan öğrencilerin başında Harp Okulu Alay Komutanı Albay Müçteba Özden vardı. Harp

48 Ahmet Yıldız, İhtilalin İçinden ..., s. 128-131.

49 Abdi İpekçi-Ömer Sami Coşar, İhtilâlin..., s. 110-111.

50 Serdar Şahinkaya, "29 Nisan 1960'da Siyasal Bilgiler Fakültesi ve Adım Adım 27 Mayıs”, Mülkiye Dergisi, C.34, S.267, 2010, s. 117

51 Cem Eroğul, Demokrat Parti: Tarihi ve İdeolojisi, 5. bs., İstanbul, Yordam Yayınları, 2014, s. 235. 
Okulu Komutanı General Sıtkı Ulay ise yürüyüşe yarı yolda katılmışt1. ${ }^{52}$ Şevket Süreyya Aydemir, cuntacı Albay Orhan Erkanlı'nın tersine bu yürüyüşe öğrencilerden çok subayların katıldığını, grubun en başında ise arabasından yürüyüşe eşlik eden General Nurettin Uluç'un olduğunu belirtmiştir. Ayrıca 27 Mayısçılardan Alparslan Türkeş ve Sezai Okan gibi isimler de okulun öğretmen kadrosundaydılar ama General Uluç’un okulla doğrudan bir bağlantısı yoktu. Sonuç olarak bu yürüyüş, herhangi bir olay olmadan öğrencilerin okullarına dönmesiyle tamamlandı. Fakat Şevket Süreyya Aydemir'in de belirttiği gibi 27 Mayıs Darbesi'nin son planlarının Harp Okulu'nda yapılması ve Albay Müçteba Özden'in 27 Mayıs gecesi darbenin işaretini vermesi, yürüyüşün çok da plansız bir şekilde gerçekleşmediğini göstermekteydi. 27 Mayıs Darbesi’nin gerçekleşmesi ise DP'nin yürüyüşten sonra Harp Okulu'nun geleceği açısından aldığı önlemlerin kendi adına yetersiz olduğunu gösterecekti. ${ }^{53} \mathrm{Bu}$ doğrultuda Ankara Sikıyönetim Komutanı Korgeneral Argüç, Harp Okulu yürüyüşünden kısa bir süre sonra belli ki bir normalleştirme çabası olarak sıkıyönetim tedbirlerinin azaltıldığını söyledi. ${ }^{54}$ Nisan ayının sonundan itibaren yaşanan bu gelişmeler, yaklaşık bir aylık bir süre içinde 27 Mayıs 1960 Darbesi'nin gerçekleşmesine engel olmayacaktı. Tabii darbenin tek nedeni DP'nin özellikle iktidarının son dönemlerindeki sertlik yanlısı politikaları ve uzlaşmaz tutumu değildi. Yukarıda da vurgulanmaya çalışıldığı gibi darbenin en temelinde ekonomik, toplumsal ve sosyal sebepler vard1.

\section{27 Mayıs 1960 Darbesi Sonrasında Sanıkların Yargılanmaları ve İtibarlarının İade Edilme Süreci}

Öncelikle 27 May1s Darbesi, sadece DP Hükûmeti'ni yönetimden düşürmekle kalmad1; DP etrafindaki onlarla çalışan bürokratik kesimlerden isimler de bundan olumsuz

52 Ayrıca MBK üyesi Orhan Erkanlı tarafından da belirtildiği gibi bu yürüyüş sırasında genelkurmay başkanının emriyle General Yusuf Demirdağ, Ankara'daki zırhlı birlikleri yanına alarak Harbiyelilerin yürüyüşünü engellemek ve onları okullarına geri döndürmek niyetindeydi. Aslında bu engelleme teşebbüsü bir önem taşımamış, öğrenciler okullarına bir sorun olmadan dönmüştü. Fakat Erkanlı'nın bu generalden bahsederken "Prusya tipi general” tanımlamasını kullanması önemlidir. Erkanlı, bu tanımlamayla muhtemelen sertlik yanlısı bir müdahale anlayışından bahsetmektedir. Nitekim Prusya, modern orduların kurulması ve yayılması konusunda ilk örnek olduğu için Genelkurmay Başkanı Erdelhun'dan başlayarak DP ile birlikte hareket eden ordu üyeleri tarafından 27 Mayıs Darbesi öncesinde Türkiye'de gösterilen tavrın eski dönemli, modern olmayan bir askerî tavır olduğu düşünülür. Bkz. Orhan Erkanl1, Askerî Demokrasi: 19601980, İstanbul, Güneş Yayınları, 1987, s. 33-38. Ayrıca yürüyüş yapan öğrencilerin etrafını getirdiği askerlerle sarma teşebbüsünde bulunan Zırhlı Tugay Komutanı General Yusuf Demirdağ, dönemin Harp Okulu Komutanı Sitkı Ulay ile bir hukukçu yüzbaşı tarafından uyarılmış ve askerlerini geri çekmeye ikna edilmişti. Çünkü sıkıyönetim hala devam ediyordu ve yürüyüş hakkında muhtemelen sadece sıkıyönetimin bir tasarrufu olabilirdi. Ayrıca General Demirdağ'ın öğrencilere herhangi bir müdahalesi, iki taraf arasında bir çatışma nedeni de olabilirdi. Bkz. Abdi İpekçi-Ömer Coşar, İhtilâlin..., s. 137-138.

53 Şevket Süreyya Aydemir, Ikkinci Adam: 1950-1964 ..., s. 419-420.

54 Feroz Ahmad-Bedia Turgay Ahmad, Türkiye'de Çok Partili..., s. 211. 
etkilendi. Darbe, hiyerarşi dışı bir şekilde gerçekleşti ve sonrasında Millî Birlik Komitesi kuruldu. Bu komite, ordu üst yönetimine nazaran daha çok alt rütbeli subayların bir araya geldiği bir oluşumdu. TSK'nın komuta kademesinin yönetimden düşürülmesi ve daha alt rütbeli subayların da MBK üyesi olmaları, mevcut emir komuta zincirini olumsuz etkileyecekti. Nitekim Hikmet Özdemir'in de belirttiği gibi darbeden birkaç ay sonra 27 Mayıs rejimi tarafından "hiyerarşi piramidini” düzeltmek için orduda yapılan tasfiyeler, bu bağlamda değerlendirilebilir. Buna göre TSK'dan beş bine yakın subay ve 235 general, artık Emekli İnkılâp Subayları (EMINSU) olarak anılacak bir oluşumun üyeleri olacaklardı. ${ }^{55}$

Sivil bazı üyelerin de katılımıyla darbenin başına geçirilen isim ise darbe öncesinin kara kuvvetleri komutanı olan Orgeneral Cemal Gürsel'di ve onun başkanlığını yaptığı hükûmetler ile yola devam edilecekti. Hukuki olarak 1961 Anayasası ortaya çıkana kadar MBK tarafından bir geçici anayasa yapıldı ve cunta yönetimi tarafından alınan kararlar böylece meşrulaştırılmış oldu. 27 Mayısçılar, bir yandan rejimlerine meşruluk kazandırırken diğer yandan da darbeyi yaparken ortaya koydukları liberal demokratik rejimin tekrar tesis edilmesiyle ilgili şartları olgunlaştırmaya çalıştılar.

Yukarıda da bahsedildiği gibi 1950’lerin ikinci yarısında -özellikle darbeden önceki birkaç yılda- ordu üst yönetimindeki bazı generallerin -Rüştü Erdelhun, Namık Argüç gibi- olaylar karşısındaki tutum ve davranışları, darbe sonrasında Yassıada'da yargılanmalarının bir nedeni olacaktı. Ama asıl neden belki de iktidar olarak kutuplaşmanın seviyesini kontrol edemeyen, olayların nedenlerini anlayamayan ve uzlaşmayan -başta Cumhurbaşkanı Celal Bayar ve Başbakan Adnan Menderes olmak üzere- DP'li muktedirlerin, göstericilere karşı sert tutum gösterme eğiliminde olan ordu üst yönetiminin radikal birer destekçisi olmalarıydı. Darbe gerçekleştiğinde ordu üst yönetiminde olan bazı isimlerin haricinde bir de 1950'lerin başından itibaren çeşitli nedenlerle ordudan ayrılmış veya ordudan emekli olan ya da DP'den milletvekili olmaları nedeniyle yargılanması öngörülen isimler de vardı. Doğal olarak bu kişiler, milletvekili olduktan sonra DP çatısı altında siyasi, hukuki, sosyal ve benzeri alanlardaki icraatlar içinde oldular. Dolayısıyla 27 Mayısçılar tarafindan yargılanmalarının öngörülmesi de bu nedenlerle olacaktı.

Eski Kara Kuvvetleri Komutanı Orgeneral Cemal Gürsel darbenin lideri yapılmadan önce, "fiili" bir lider olarak General Cemal Madanoğlu, darbe sabahı kimlerin tutuklanacağıyla ilgili kararları verdi. Hareket sonrası yeterince planlanmadığından darbe sonrasında Harp Okulu'na yüzlerce kişi getirilmişti. Oysa Şevket Süreyya Aydemir'in General

55 Hikmet Özdemir, Türkiye Cumhuriyeti, İstanbul, İz Yayıncılık, 1995, s. 256-257. Bununla ilgili "5434 sayılı Türkiye Cumhuriyeti Emekli Sandı̆̆ Kanununa ek Geçici Kanun” adıyla çıkarılan 42 sayılı kanun metni için bkz. Resmî Gazete, S.10570, 5.8.1960, s. 1893. 
Madanoğlu'ndan aktardığı kadarıyla sadece Kabine üyeleri ve Tahkikat Komisyonu imzacıS1 dört üyeyi tutuklamak amaçlanmıştı. Bu yüzden Madanoğlu'nun kararıyla üst düzey hükûmet üyeleri hariç Harp Okulu'na getirilen yaklaşık 150 kişi, darbenin hemen ardından serbest bırakıldı. ${ }^{56} 27$ Mayıs Darbesi sonrasında Albay Alparslan Türkeş tarafindan okunan darbe bildirisinde geçen şu sözler bu durumu biraz açıklıyordu: "Girişilmiş olan bu teşebbüs, hiçbir şahsa veya zümreye karşı değildir." ${ }^{57}$ Ancak darbecilerin bu öngörüsünün ne kadar gerçekleştiği farklı bir konudur ve bu çalışmanın sınırlarını aşar.

General Madanoğlu'nun girişimiyle serbest bırakılan kişiler; yine Madanoğlu tarafından bir anayasa yapmakla görevlendirilen akademisyenlerin, 27 Mayısçıların rejimlerini meşru kabul ettirmekte zorlanabileceklerini ve bu nedenle bu kişilerin serbest b1rakılmalarının yanlış olduğunu belirtmeleri nedeniyle tekrar tutuklandı. Çünkü akademisyenlere göre anayasa ihlal edilmişti ve bunun sorumluları vard1. Bu yüzden de Harp Okulu'na getirileceklerin listesi sürekli değişti ve şüpheli sayısı arttı. Tabii bunların içinde çeşitli rütbelerden ordu üyeleri de vard1. ${ }^{58} \mathrm{Bu}$ süreçte DP politikalarına ortak oldukları gerekçesiyle tutuklanacak mevcut asker ya da asker kökenli DP milletvekillerinin bir kısmı serbest bırakılırken; 27 Mayıs öncesi süreçte bir şekilde rol oynayan asker kökenli birçok ordu üyesi de Yassıada'da yargılanacaktı.

Darbenin ardından Zırhlı Birlikler Komutanı Yusuf Demirdağ ve Genelkurmay Başkanı Rüştü Erdelhun evlerinden; Ankara Sıkıyönetim Komutanı Korgeneral Namık Argüç, Kara Kuvvetleri Komutan Vekili Suat Kuyaş ve diğer birçok general ise sonrasında MBK üyesi olacak olan Kurmay Yüzbaşı İrfan Solmazer tarafindan Ankara Orduevi'nden alınarak Harp Okulu'na getirildi. 27 Mayıs Darbesi'nin ana merkezi, Sıkıyönetim Komutanlığı Karargâhı idi. Bazı generaller ise kendi imkanlarıyla karargâha gelmişlerdi. Bunlardan biri olan Hava Kuvvetleri Komutanı Orgeneral Tekin Arıburun, bir diğer MBK üyesi Kurmay Albay Sami Küçük'ün aktardığı kadarıyla darbeyi onaylamadığını General Madanoğlu'na söylemiş ve bu nedenle Harp Okulu'na gönderilmişti. ${ }^{59}$

56 Şevket Süreyya Aydemir, İhtilâlin Mantı̆̆l, 2. bs., İstanbul, Remzi Kitabevi, 1976, s. 351-353.

57 Tekin Erer, “27 Mayıs Düşmanları!”, Son Havadis, Y.14, S.2070, 27.5.1966, s. 3.

58 Bu ilk listede, ileride Yassıada'da yargılanacak olanlardan eski bir ordu üyesi ve son dönem DP Milletvekili General Fevzi Uçaner ve 27 Mayıs Darbesi olduğunda mevcut bir ordu üyesi olan Kemal Çakın vardı. İçinde farklı ordu üyelerini isimleri de bulunan listenin geniş bir hali için bkz. Şevket Süreyya Aydemir, Ihtilâlin..., s. 353-366; Şevket Süreyya Aydemir, Ikkinci Adam: 1950-1964 ..., s. 456-457. Ayrıca Abdi İpekçi ve Ömer Samir Coşar'ın verdiği bilgilere göre 27 Mayıs Darbesi sonrasında tutuklanacak ilk listelerde Aydemir'e ek olarak Genelkurmay Başkanı Rüştü Erdelhun da vardı. Bkz. Abdi İpekçi-Ömer Sami Coşar, İhtilâlin..., s. 189.

59 Sami Küçük, Rumeli'den 27 Mayıs'a: Ihtilalin Kaderini Belirleyen Köşk Harekâtı, İstanbul, Mikado Yayınları, 2008, s. 101. Orgeneral Suat Kuyaş, Konya'da bulunan İkinci Ordu'nun komutanıydı ve Yeşilhisar olayları sırasında da Kayseri bölgesinden sorumluydu. Bu yüzden Cumhurbaşkanı Celal Bayar, CHP lideri İsmet İnönü'nün Yeşilhisar bölgesine yapması muhtemel bir ziyaret nedeniyle bölgede sıkıyönetim ilan edilmesini Kuyaş’tan istemiş; dolayısıyla İnönü’nün bu hamlesiyle mücadele etmek Kuyaş’a düşmüştü. Bkz. Adnan Çelikoğlu, Bir Darbeci Subayın ..., s. 111. 
Nitekim 27 Mayısç1lar o gün birçok asker bürokrat ya da DP'li siyasetçinin kaderini belirledi. Örneğin daha sonra genelkurmay başkanı ve cumhurbaşkanı olacak olan ve o dönemde genelkurmay ikinci başkanı da olan Orgeneral Cevdet Sunay’ın da Madanoğlu tarafından Harbiye' de tutulmasına gerek görülmemişti. ${ }^{60}$ Sonuç olarak DP'nin yanında olduğu açıkça belli olan asker kökenli tüm ordu üyelerinin 27 Mayıs Darbesi sonrasında Yassıada'ya götürülüp yargılandığı söylenemez. Bu bağlamda bir aşamada serbest bırakılan, hakkında işlem yapılan, en azından yargılama amaçlı Yassıada'ya götürülen, DP'ye yakın ya da yakın görülen mevcut ordu üyelerinin veya asker kökenli milletvekillerinin listesi tespit edilebildiği kadarıyla şöyledir:

\begin{tabular}{|c|c|c|c|c|c|}
\hline Sira & Parti & İsim & Rütbe & Dönem & Açıklama \\
\hline 1 & $\mathrm{DP}$ & Arslan Nihat Bekdik & & $\mathrm{XI}$ & İstanbul Milletvekili \\
\hline 2 & DP & Cemil Şener & Tabip Binbaşı & $\mathrm{XI}$ & Manisa Milletvekili \\
\hline 3 & DP & Doğan Köymen & Subay & IX-X-XI & Giresun Milletvekili \\
\hline 4 & DP & Hulki Amil Keymen & Tbp. Albay & $\mathrm{XI}$ & Konya Milletvekili \\
\hline 5 & DP & Hüseyin Ülkü & As. Tbp. & IX-X-XI & $\begin{array}{l}\text { IX. ve X. Dönem Niğde, } \\
\text { XI. Dönem Diyarbakır } \\
\text { Milletvekili }\end{array}$ \\
\hline 6 & DP & Mucip Kemalyeri & & $\mathrm{XI}$ & İstanbul Milletvekili \\
\hline 7 & DP & Mustafa Zeren & Albay & IX-X-XI & $\begin{array}{l}\text { IX.-XI. Dönem Erzurum, X. } \\
\text { Dönem Amasya Milletvekili }\end{array}$ \\
\hline 8 & DP & Kamil Tayşi & As. Tbp. & IX-XI & Diyarbakır Milletvekili \\
\hline 9 & DP & Yakup Karabulut & As. Hak. Yb. & XI & İçel Milletvekili \\
\hline 10 & DP & Ali Rıza Karaca & Tbp. Yarbay & $\mathrm{X}-\mathrm{XI}$ & Denizli Milletvekili \\
\hline 11 & DP & N. Fuat Alpkartal & Yarbay & $\mathrm{X}-\mathrm{XI}$ & Çanakkale Milletvekili \\
\hline 12 & $\mathrm{DP}$ & İshak Avni Akdağ & Orgeneral & $\mathrm{X}-\mathrm{XI}$ & $\begin{array}{l}\text { X. Dönem Erzurum, XI. } \\
\text { Dönem Konya Milletvekili }\end{array}$ \\
\hline 13 & DP & Nurettin Aknoz & Orgeneral & $\mathrm{XI}$ & Tekirdağ Milletvekili \\
\hline 14 & DP & Nuri Yamut & Orgeneral & $\mathrm{X}-\mathrm{XI}$ & İstanbul Milletvekili \\
\hline 15 & DP & Nazmi Ataç & Orgeneral & $\mathrm{XI}$ & İstanbul Milletvekili \\
\hline 16 & DP & Muhlis Erdener & & $\mathrm{X}-\mathrm{XI}$ & Bursa Milletvekili \\
\hline 17 & DP & Fevzi Uçaner & Orgeneral & $\mathrm{XI}$ & İzmir Milletvekili \\
\hline 18 & DP & Sadık Altıncan & Oramiral & $\mathrm{XI}$ & Giresun Milletvekili \\
\hline 19 & DP & Tahsin Yazıcı & Tümgeneral & $\mathrm{X}-\mathrm{XI}$ & İstanbul Milletvekili \\
\hline 20 & DP & Yümnü Üresin & Korgeneral & IX-X-XI & Bilecik Milletvekili \\
\hline 21 & DP & Zihni Üner & Tuğgeneral & $\mathrm{X}-\mathrm{XI}$ & $\begin{array}{l}\text { X. Dönem Niğde, } \\
\text { XI. Dönem Nevşehir } \\
\text { Milletvekili }\end{array}$ \\
\hline 22 & & Mustafa Rüştü Erdelhun & Orgeneral & & $\begin{array}{l}27 \text { Mayıs Darbesi Sırasında } \\
\text { Genelkurmay Başkanı }\end{array}$ \\
\hline 23 & & Namık Argüç & Korgeneral & & $\begin{array}{l}\text { Ankara Sıkıyönetim } \\
\text { Komutanı }\end{array}$ \\
\hline 24 & & Kemal Binatlı & Tümgeneral & & İstanbul Merkez Komutanı \\
\hline
\end{tabular}

60 Adnan Çelikoğlu, Bir Darbeci Subayın..., s. 140. 


\begin{tabular}{|c|c|c|c|c|c|}
\hline 25 & & Kemal Çakın & & & $\begin{array}{l}\text { Yeşilhisar Olayında Kayseri } \\
\text { Garnizon Komutanı }\end{array}$ \\
\hline 26 & & Tekin Arıburun & Orgeneral & & Hava Kuvvetleri Komutanı \\
\hline 27 & DP & Seyfi Kurtbek & Kurmay Albay & IX-X & Ankara Milletvekili \\
\hline 28 & & Avni Karaca & Yarbay & & \\
\hline 29 & & Salih Coşkun & Orgeneral & & \\
\hline 30 & & Sait Yöner & Subay & & \\
\hline 31 & & Yusuf Demirdağ & Tuğgeneral & & \\
\hline 32 & & Arif Onat & Tümgeneral & & $\begin{array}{l}\text { Millî Müdafaa Vekâleti Askerî } \\
\text { Adalet İşleri Başkanı Hâkim }\end{array}$ \\
\hline 33 & & Halil Güney & Tümgeneral & & 51. Tümen Komutanı \\
\hline 34 & & Suat Kuyaş & Orgeneral & & \\
\hline 35 & & Tahsin Çelebican & Orgeneral & & Jandarma Genel Komutanı \\
\hline
\end{tabular}

Tablo 1: Yassıada'da yargılanan; DP'den siyasete atılmış ya da DP'ye yakın olduğu düşünülen eski asker bürokratlar veya 27 Mayıs Darbesi'ne gidiş sürecinde rolü görülen aktif ordu mensuplarının listesi ${ }^{61}$

Yassıada'daki yargılamalar 14 Ekim 1960’te başladı. 31 Ekim 1960 tarihine kadar tutuklanmalarına dair kendileriyle ilgili bir karar olmayan bir kısım sanık, Yassıada'dan tahliye edildi. Bunların içinde asker kökenli bir DP'li siyasetçi olan Em. Kurmay Albay Seyfi Kurtbek, Emekli Subay Sait Yöner, yine DP milletvekili olarak Yassıada'da yargılanan Perihan Arıburun'un eşi, 27 Mayıs Darbesi sırasında hava kuvvetleri komutanı olan Tekin Arıburun ve General Kemal Çakın -Çakın daha sonra suçlu bulunup ceza alacaktır- da vard1. ${ }^{62}$ Yassıada Mahkemeleri 15 Eylül 1961 tarihinde sonuçlandı. Zamanla Yassıada'dan tahliye edilen ya da orada hayatını kaybeden asker kökenli sanıkların dışında yukarıda listede bulunan tüm sanıklar, Yassıada'da belirli ölçülerde cezalar aldı. Bunların arasından DP'li muktedirler başta olmak üzere on beş kişiye idam cezası verildi. Bu sanıklardan Adnan Menderes, Fatin Rüştü Zorlu ve Hasan Polatkan'ın cezaları infaz edildi. Eski Genelkurmay Başkanı Rüştü Erdelhun ve yine asker kökenli bir DP'li siyasetçi olan Muhlis Erdener'in cezaları, diğer on sanıkla birlikte müebbet hapis cezasına çevrildi. ${ }^{63}$

Diğer yandan Yassıada' daki yargılama sürecinde DP'li birçok isim hayatını kaybetti. Bunlardan bir tanesi eski Genelkurmay Başkanı ve DP Milletvekili Orgeneral Nuri Yamut'du. Yamut'un ölüm nedeni kalp krizi olarak duyurulsa da diğer sanıklar tarafından Orgeneral Yamut'un aslında Yassıada'da kendisine gösterilen muamele yüzünden

61 TBMM Albümü: 1920-2010, C.II, Ankara, TBMM Basın ve Halkla İlişkiler Müdürlüğü Yayınları No.1, 2010.

62 Tekin Erer, Yassiada ve Sonrası, İstanbul, Rek-Tur Kitap, 1965, s. 513-514.

63 Yassıada'da sanıkların aldıkları cezalar ve detayları için bkz. Yüksek Adalet Divanı Kararları: 14 Ekim 1960-15 Eylül 1961, İstanbul, Kabalcı Yayınevi, 2007, s. 342-397. Kimin ne kadar ceza aldığı ve davalardan beraat edenlere yönelik daha kısa bir değerlendirme için bkz. Tekin Erer, Yassıada ve..., s. 616-624. 
öldüğü iddia ediliyordu. Yargılamalar sırasında hayatını kaybeden diğer isim ise yine eski bir korgeneral ve DP'li siyasetçi olan Yümnü Üresin'di. ${ }^{64}$

Kararlar açıklanıp idamların infazı gerçekleştikten sonra sanıkların Türkiye' deki farklı cezaevlerine nakledilme süreci başladı. Bunlardan 297 mahkûm -müebbet ceza alan 43 sanık da sonradan bu sayıya eklenecekti- Kayseri Cezaevi’ne, 113 mahkûm ise Adana Cezaevi'ne gönderildi. Bu mahkûmlardan biri de 27 Mayıs öncesindeki Ankara olayları sırasında sıkıyönetim komutanı olan Korgeneral Namık Argüç’tü. İçlerinde eski bir orgeneral ve siyasetçi İshak Avni Akdağ'ın da olduğu sekiz mahkûm, hastalıkları nedeniyle bir cezaevi hastanesinde kalacaktı. Sonuç olarak mahkûmların çoğu Kayseri Cezaevi'ne konuldu. ${ }^{65}$ Kayseri Cezaevi'nde de kalp hastalığından hayatını kaybeden mahkûmlar da oldu. Bunlardan biri de ilk olarak müebbet hapis cezasına çarptırılan Muhlis Erdener'di. Cumhurbaşkanı Celal Bayar, onun rahatsızlık sürecine tanık olduğunu ve bu gibi hastaların evlerinde tedavi edilselerdi ölüm gibi bir sonuçla karşılaşılmayacağını belirtmişti. Dolayısıyla mahkûmların bu şekildeki ölümlerinin sebebi, DP çizgisi mensupları tarafından 27 Mayıs rejimi olarak görüldü. ${ }^{66}$

Sanıkların cezalarının kesinleşmesi ve Yassıada'dan başka yerlere nakledilmelerinden sonra şu şekildeki birkaç noktayı ele almak gerekecektir: Birincisi DP Hükûmeti ile birlikte çalıştığı düşünülen ve yukarıda örneği verildiği gibi DP otoriterliğinin yansıtılmasında payı görülen birçok generalin emekliye sevk edilmesiydi. Yavuz Özgüldür'ün ilgili kanundan aktardığı kadarıyla içlerinde Rüştü Erdelhun, Suat Kuyaş, Salih Coşkun, Tekin Arıburun, Namık Argüç, Halil Güney, Kemal Binatlı, Arif Onat, Yusuf Demirdağ ve Kemal Çakın'ın da olduğu generaller, 27 Mayıs Darbesi’nin üzerinden henüz bir

64 H. Emre Oktay, Menderes 'in Gözyaşlart: Yassıada, İstanbul, Akis Kitap, 2014, s. 268; Erdal Şen, Başbakan Adnan Menderes'in Hayatı: Bir Yiğit Vard, İzmir, Yitik Hazine Yayınları, 2011, s. 248. Emekli Orgeneral Nuri Yamut, 5.6.1961 tarihinde kaldığı hastanede vefat etmişti. Bkz. Cumhuriyet, 6.6.1961, s. 1. Emekli Korgeneral Yümnü Üresin, uzun süredir tedavi olduğu bir hastalıktan dolayı 29.5.1961 tarihinde hayatını kaybetmişti. Bkz. Cumhuriyet, 30.5.1961, S. 1 .

65 Sanıklar Kayseri Cezaevi’ne getirilmeden önce kalan mahkûmlar, çevre bölgelerdeki cezaevlerine gönderilmiş ve Kayseri Cezaevi sadece DP'li çizgide görülerek yargılanan sanıklara tahsis edilmişti. Ayrıca sanıklar oraya gelmeden önce cezaevi elden geçirilmiş ve yenilenmişti. Bkz. "Kayseri Cezaevindeki Hazırlıklar Tamamlandı", Cumhuriyet, 19.9.1961, s. 1, 5. Yassıada sanıklarının farklı cezaevlerine nakilleriyle ilgili MBK kararı ve konuyla ilgili detaylı bilgi için bkz. "Yassıada mahkûmları uçaklarla İmralı, Adana Kayseriye nakledildi”, Cumhuriyet, 20.9.1961, s. 1, 5; Tekin Erer, Yassiada ve..., s. 632-636.

66 Celal Bayar: Kayseri Cezaevi Günlügü,, 3. bs., haz. Yücel Demirel, İstanbul, Yapı Kredi Yayınları, 2018, s. 54-55. Muhlis Erdener, 17 Ocak 1962 tarihinde hayatını kaybetmiş̧i. Bkz. Milliyet, 18.1.1962, s. 1. 
hafta bile geçmeden TSK' dan emekli edildi. ${ }^{67} \mathrm{Bu}$ isimlerin haricinde dört muvazzaf asker, emekli yapılmak suretiyle TSK' dan ayrılmış oldu. Emekli edilen ordu mensuplarından nezaret altına alınan sekiz üst rütbeli general, iki de onlara göre daha alt rütbeden subay vard1. ${ }^{68}$

Cezaevlerindeki emekli asker-bürokratlar için süreçteki ikinci bir kırılma noktası ise onların askerlik statülerinin düşürülüp orduyla olan bağlarının tamamen kesilmesiydi. Bu bağlamda emekli orgeneraller Rüştü Erdelhun, Nazmi Ataç, Nurettin Aknoz, Fevzi Uçaner ve İshak Avni Akdağ, emekli tümgeneraller; Tahsin Yazıcı ve Kemal Binatlı, emekli tuğgeneraller; Kemal Çakın ve Zihni Üner, Emekli Korgeneral Namık Argüç gibi on general, 15 Haziran 1962 tarihinde ordudan tardedildi. Yedek subaylık haklarıysa 24 Nisan 1963 tarihinde ellerinden alındı. ${ }^{69}$ Emekli konumda bulunan bu generallerin orduyla bağlantılarının kesilmesi, kendilerinin ve ailelerinin ilerleyen dönemde ekonomik sıkıntılar çekmeleri anlamına da geliyordu. ${ }^{70}$ Tabii bu, cezaevindeki asker kökenli sanıklar için hem oradan çıkmalarına hem de mesleklerine geri dönmelerine yönelik bir af ihtiyacının ortaya çıkması demekti.

67 Sanıklardan Orgeneral Salih Coşkun'un ve Tuğgeneral Yusuf Demirdağ’’n tutuksuz yargılanmalarına karar verilmişti. Bu iki ismin ardından Dokuz Subay Olayı diye bilinen başarısız darbe girişiminde bulunanları yargılayan Hâkim General Arif Onat da 13 Kasım 1960 tarihinde tutuksuz yargılanmak üzere kaldığı cezaevinden tahliye edildi. Bkz. "Mevkuf hakim General Onat'da tahliye edildi”, Yeni İstanbul, Y.11, S.3952, 14.11.1960, s. 5. Bu isimlerden Tuğgeneral Yusuf Demirdağ, 1961 yılında AP'den senatör olmuştur. Bir diğer deyişle cuntacılar tarafından varlığında sorun görülmeyen darbe öncesi ordu üyelerinin tekrardan sosyal yaşamlarına dönmelerine izin verilmekteydi. Ayrıca emekli edilen ordu mensuplarıyla ilgili kararname için bkz. Yavuz Özgüldür, Orgeneral..., s. 292. AP'den Trabzon ili senatörü olan Yusuf Demirdağ, Devlet Başkanı Cemal Gürsel 25 Ekim 1961 tarihinde TBMM'yi açmak için meclise girdiğinde ayağa kalmayan isimler arasındaydı. MBK üyelerinden Sıtkı Ulay, Demirdağ'ın bu tavrına tepki göstermişti. Bu davranışı, eski bir ordu üyesi olan Demirdağ'ın tarafının belli olması açısından önemli olsa gerektir. Bkz. Düşünen Adam, 2.11.1961, s. 5-6. Diğer yandan 26 Mayıs'1 27 Mayıs'a bağlayan geceyi “terör gecesi” olarak adlandıran Gazeteci Nizamettin Nazif Tepedelenlioğlu, General Kemal Binatlı'nın Kurtuluş Savaşı öncesinde başlayan süreçten yani harp okulundaki öğrenciliğinden itibaren önemli görevlerde bulunduğunu ve böyle "milli” hizmetlerde bulunan bir generalin nasıl bu şekilde emekli edilerek ordudan uzaklaştırılabildiğini eleştirel bir dille sorguluyordu. Bkz. Nizamettin Nazif Tepedelenlioğlu, "General Kemal Binatlı ve son tarihî ifşaat”, Yeni İstanbul, 8.2.1967, s. 3.

68 Cumhuriyet gazetesinde verilen bilgiye göre Orgeneral Tahsin Çelebican da emekli edilen subaylar arasına katılmıştı. Bu süreçte serbest bırakılan iki general ise İkinci Ordu Komutanı Orgeneral Suat Kuyaş ve Orgeneral Tahsin Çelebican'dı. Bkz. Cumhuriyet, 23.6.1960, s. 1, 5. Ayrıca serbest bırakılan generallerden Salih Coşkun ve Suat Kuyaş'ın Ankaraİstanbul davalarında tanık olarak dinlendiği de belirtilmelidir. Bkz. Fatih Uğur-Mustafa Gürlek, 50 Yıllık Sir..., s. 216228.

69 Yavuz Özgüldür, Orgeneral ..., s. 266. Ayrıca emekli durumda bulunan bu generallere birkaç örnek vermek gerekirse: Orgeneral Nurettin Aknoz'un yedek subaylık hakkının elinden alındığı belge için bkz. T.C. Cumhurbaşkanlı̆ğ Devlet Arşivleri Başkanlı̆̆ Cumhuriyet Arşivi (BCA), Fon Kodu: 030.11.1.0, Yer No: 297.12.18, 24.4.1963. Korgeneral Namık Argüç'ün yedek subaylık hakkının elinden alındığı belge için bkz. $B C A$, Fon Kodu: 30.11.1.0, Yer No: 297.12.16, 24.4.1963. Emekli Tümgeneral Kemal Binatı'nın yedek subaylık hakkının elinden alındığı belge için bkz. $B C A$, Fon Kodu: 30.11.1.0, Yer No: 297.12.20, 24.4.1963.

7027 Mayıs öncesinin Genelkurmay Başkanı Rüştü Erdelhun bu generallerden biriydi. Bkz. Yavuz Özgüldür, Orgeneral ..., s. 267-268. Diğer bir örnek Korgeneral Namık Argüç'ün, darbeden yaklaşık iki hafta sonra gösterilerin olduğu tarihte bir bankadaki hesabına yattığı ilan edilen bir miktar parasına el konulmasıydı. "Argüç'ün 260 bin lirası donduruldu", Yeni İstanbul, 15.6.1960, s. 1. 
Bu doğrultuda asker kökenli sanıklardan Mustafa Rüştü Erdelhun, 25 Eylül 1964 tarihindeki kararnameyle "tıbben tesbit olunan sürekli hastalık, sakatlık ve kocama hali sebebiyle, cezasının tamamen kaldırılması, Türkiye Cumhuriyeti Anayasa'sının 97 nci maddesi 2 nci fikrasl gereğince" ${ }^{71}$ Cumhurbaşkanı Cemal Gürsel'in sağlık sorunları bulunan sanıkları affetme hakkını kullanmasıyla tahliye edilecekti. ${ }^{72}$ Yine bu doğrultuda Yassıada sanıklarını ilgilendiren ölçüde bir genel af, "Bazı Suç ve Cezaların Affı Hakkında Kanun" adıyla çıkan 780 numaralı kanunla 3 Ağustos 1966 tarihinde kabul edilmiş ve bu kanun, 9 Ağustos 1966'da Resmî Gazete'de yayımlanarak yürürlüğe girmişti. Aslında bu kanunun Yassıada sanıklarının affını ilgilendiren kısmı yani 5. Madde, önce meclis tarafindan kabul edilmiş daha sonra "Cumhuriyet Senatosu Anayasa ve Adalet Komisyonu" tarafından metinden çıkarılmıştı. Fakat kanunun bu bölümü daha sonra yeniden yasa metnine eklendi. Ayrica söz konusu kanunun 5. maddesinde " $b u$ madde hükmünden faydalanan askeri şahısların askeri ceza kanununun 31 ve 33 üncü maddeleri A bendleri gereğince kaybedilen hakları geri verilir" denilerek yukarıda ordudan tardedildiği ve yedek subaylık statülerinin düşürüldüğü söylenen on emekli generalin hakları yeniden kendilerine teslim edildi. ${ }^{73}$

Yine Son Havadis gazetesinde yer alan bir habere göre Yarbay Avni Karaca da rütbesi kendisine iade edilen eski ordu mensupları arasındaydı. Böylece bu kişiler mesleklerinin kendilerine verdiği hazzı tekrar yaşayabileceklerdi. Diğer yandan haberde “Yassıada'da yedeksubaylıktan "nefer”liğe düşürülenlerin durumları da yeni karara göre düzenlenecek” denilerek Yassıada' da bulunan asker kökenli birçok sanığın rütbelerine tekrardan kavuşma haklarının belireceğinden bahsediliyordu. ${ }^{74}$ Dolayısıyla bu afları sadece on general ve birkaç subay üzerinden düşünmek yerine daha genel bir çerçevede -belki hala cezasını çekmekte olan asker kökenli sanıklar için- düşünmek gerekir. ${ }^{75}$

71 Resmî Gazete, S.11817, 26.9.1964, s. 4.

72 Gürsel aynı zamanda üç eski DP'li siyasetçinin de affını sağlayacaktı. Bkz. "Gürsel; Koraltan, Erdelhun, Ökmen ve Yatağan'1 affetti", Cumhuriyet, 23.9.1964, s. 1,7.

73 Resmî Gazete, S.1270 (Mükerrer), 9.8.1966, s. 1-2; Yavuz Özgüldür, Orgeneral..., s. 266-267; "Yassıda mahkûmlar1 da af kapsamı içine alındı", Yeni İstanbul, 30.7.1966, s. 1, 7.

74 “Erdelhun ve Binatlı'nın Rütbeleri İade Edildi”, Son Havadis, Y.15, S.2415, 11.7.1967, s. 1, 7. Yarbay Avni Karaca, "Istanbul-Ankara olayları"nın sanıklarındandı ve yargılama sonucunda 2 yıl 4 ay hapis, 1 sene 2 ay memuriyetten menedilme ve kendisinden 85 lira maktu harç alınmasına yönelik bir ceza almıştı. Bkz. Yüksek Adalet Divanı Kararları: 14 Ekim 1960-15 Eylül 1961, İstanbul, Kabalcı Yayınevi, 2007, s. 342-397.

75 Dönemin Adalet Bakanı AP'li Hasan Dinçer, 27 Mayıs Darbesi'nden sonra yargılanan suçluların 51 tanesinin emeklilik haklarının kendilerine verildiğini söyleyecektir. Bu sayının kaçının asker kökenli ordu üyelerine ait olduğu bilinmese de yukarıda belirtilenler haricindeki üyelerinin de aftan yararlanabileceği varsayılabilir. Bkz. "Meclis af tasarısını Senatodan gelen şekliyle kabul etti”, Yeni İstanbul, Y.14, S.2139, 4.8.1966, s. 1, 5. 
En azından bu, DP/AP çizgisi mensupları için 27 Mayıs 1960’tan beri kendi aleyhlerine gördükleri bir sorunun çözülmesi olarak değerlendirilmiştir. Mesela kendisi de eski bir DP milletvekili olan Son Havadis gazetesi yazarı Mümtaz Faik Fenik, Tümgeneral Tahsin Yazıcı'nın gazetelerinde yer verdiği Kore anılarının altına "Emekli General" diye yazamamanın hem kendileri ve hem de tabii ki eski ordu üyeleri adına üzücü olduğunu belirtmişti. ${ }^{76}$ Son Havadis gazetesi yazarı Orhan Seyfi Orhon ise Onuncu Genelkurmay Başkanı Orgeneral Rüştü Erdelhun ve onunla aynı durumda olan asker kökenli sanıkların aflarına sevinmiş; bir genelkurmay başkanının "siyasi" nedenlerle idam edilse bile rütbesinin, -hiyerarşi dış1lık gözetilerek- erlik statüsüne indirilemeyeceğinden bahsetmişti. ${ }^{77}$ Böyle bir durum hem Türk sağının ordu tahayyüllerine aykırıydı hem de bir zamanlar TSK'nın en üst rütbesinde başarılı görevlerde bulunmuş bir generalin bu durumlara düşürülmesi, görevi güvenliği sağlamak olan ordunun uluslararası alandaki görünürlüğü açısından olumsuz bir gelişmeydi.

\section{Sonuç}

DP'li muktedirler, iktidara geldikten sonra doğal olarak ordu üst yönetimini -daha önce CHP'nin de yaptığı gibi- kendi siyasi görüşlerine yakın, birlikte çalışabilecekleri isimlerden oluşturdu. Bu şekilde, hiyerarşik bir yapının geçerli olduğu ordu içindeki üstünlük DP'ye geçmiş oldu. Sonrasında ise Nuri Yamut ve Yümnü Üresin gibi ordu üst yönetimindeki emekli generaller, DP saflarında siyasete katılma yolunu seçti. Ayrıca en son örneğini Onuncu Genelkurmay Başkanı Rüştü Erdelhun'un oluşturduğu asker bürokratlar da doğrudan 27 Mayıs Darbesi'nin hedefi oldular. İçlerinde Nurettin Aknoz, Namık Argüç ve Kemal Binatlı gibi ordu üyelerinin de olduğu bir grup üst düzey ordu yöneticisi, aslında protestoculara karşı hükûmetle birlikte hareket etmekte haklıydı. Ama bu üyeler, Cumhurbaşkanı Celal Bayar ve Genelkurmay Başkanı Orgeneral Rüştü Erdelhun'un da katkılarıyla ellerindeki gücü göstericilere karşı sert bir şekilde kullanmaktan çekinmedi. Bu durum, toplumsal alanda olduğu gibi ordu içindeki kutuplaşmayı da arttırıcı bir etken oldu ve sonucunda 27 Mayıs Darbesi gerçekleşti.

Darbe sonrasındaki Yassıada yargılamaları, sadece asker kökenli sanıklar için değil DP'liler için de aslında hukuka uygun, tarafsız kararların alınmadığını kesinlikle göstermiştir. Nitekim darbeler konusunda yapılan araştırmaların -tabii bu doğrudan hükûmet darbesiyse- çoğu, iktidarların darbe sonrasındaki konumlarına odaklanmıştır. Darbelerin

76 Mümtaz Faik Fenik, "Yassıada'da mâhkum edilen generaller!.., Son Havadis, 17.7.1967, s. 1. Fakat bu tabirin kullanılabildiği yazılar da vardı. bkz. "Gnl. Tahsin Yazıcının Celâl Doraya cevabı”, Yeni İstanbul, 8.4.1963, s. 3.

Orhan Seyfi Orhon, "Sevindim”, Son Havadis, 15.7.1967, s. 2. 
genelde hükûmete yönelik hareketler olarak değerlendirilmesi nedeniyle ordu üst yönetiminin düşürülmesi, genelde ilk planda akla gelen ya da belki bir araştırma açısından ilk planda vurgulanan bir husus değildir. Nitekim 27 Mayıs Darbesi'nden sonra Türkiye'de başarılı ya da başarısız, hatta alt rütbeli subayların da kalkıştı̆̆ birçok darbe girişimi gerçekleşmiş ama bunlardan hiçbirisinde ordu üst yönetimi düşürülmemiştir.

Burada yine vurgulamak gerekir ki 27 Mayıs Darbesi, TSK'nın komuta kademesi tarafından yapılmış bir darbe değildir. Nitekim 12 Mart 1971 ve 12 Eylül 1980 süreçlerinde genelkurmay başkanları ve kuvvet komutanlarını bizzat görmek mümkündür. 27 Mayıs Darbesi hem bu özelliğiyle hem de darbe sonrasında asker kökenli, emekli ya da mevcut ordu üyelerinin yargılanmaları, ceza almaları ve affedilmeleri bağlamında modern Türk tarihinde bir ilktir. Bu af sürecini 27 Mayıs Darbesi'nden olumsuz anlamda etkilenen ve ona karşı mücadele eden Türk sağının, özellikle DP/AP geleneğinin mücadelesi paralelinde değerlendirmek gerekir. Örneğin bir Yassıada sanı̆̆ı eski asker bürokrat ya da eski asker DP'li milletvekili, sürecin afla sonuçlanması için bireysel olarak da mücadele etmiştir. Fakat özellikle 1965 yılında AP'nin tek başına iktidara gelmesi, AP'ye 27 Mayıs uygulamalarının kendi aleyhine olan özelliklerini hukuksal olarak hafifletme firsatı vermiştir. $\mathrm{Bu}$ durum, siyasi ortamın/havanın -geride sadece radikal 27 Mayısçılar kalacak olsa da- çoğunluğu DP/AP'li kesimlere mensup 27 Mayıs süreci mağdurlarının lehine dönmesine neden olacaktır. Buna paralel olarak Yassıada'da yarg1lanan emekli asker bürokratlar ya da DP'li Yassıada sanıklarının sorunları daha erken bir tarihte çözülmüş ve sanıklara, rütbeleri bağlamındaki itibarları iade edilmiştir.

Hakem Değerlendirmesi: Dış bağımsız.

Çıkar Çatışması: Yazar çıkar çatışması bildirmemiştir.

Finansal Destek: Yazar bu çalışma için finansal destek almadığını beyan etmiştir.

Peer-review: Externally peer-reviewed.

Conflict of Interest: The author has no conflict of interest to declare.

Grant Support: The author declared that this study has received no financial support. 


\section{KAYNAKÇA}

\section{Arşiv Kaynaklari ${ }^{78}$}

Türkiye Cumhuriyeti Cumhurbaşkanllğı Devlet Arşivi Başkanlığl Cumhuriyet Arşivi (BCA)

\section{Resmî Yayınlar ${ }^{79}$}

Resmî Gazete

TBMM Albümü: 1920-2010, C.II, Ankara, TBMM Basın ve Halkla İlişkiler Müdürlüğü Yayınları No.1, 2010.

\section{Süreli Yayınlar ${ }^{80}$}

Akis

Cumhuriyet

Düşünen Adam

Milliyet

Son Havadis

Yeni İstanbul

\section{Araştırma Eserler}

Ahmad, Feroz-Turgay Ahmad, Bedia: Türkiye'de Çok Partili Politikanın Açıklamalı Kronolojisi (1945-1971), Ankara, Bilgi Yayınevi, 1976.

Ahmad, Feroz: Modern Türkiye'nin Oluşumu, 15. bs., çev. Yavuz Alogan, İstanbul, Kaynak Yayınları, 2016.

Akyaz, Doğan: Askerî Müdahalelerin Orduya Etkisi: Hiyerarşi Dışı Örgütlenmeden Emir Komuta Zincirine, 3. bs., İstanbul, İletişim Yayınları, 2009.

Armağan, Servet: "Türkiye'de Parlamento Seçimleri”, İstanbul Üniversitesi Hukuk Fakültesi Mecmuası, C.33, S.3-4, 1967, s. 45-100.

Atılgan, Gökhan: "Tarımsal Kapitalizmin Sancağ1 Altında", Osmanlı'dan Günümüze Türkiye'de Siyasal Hayat, 3. bs., haz. Gökhan Atılgan, Cenk Saraçoğlu, Ateş Uslu, İstanbul, Yordam Kitap, 2019, s. 393-520.

78 Kullanılan belgelerin künyeleri dipnotlarda gösterilmiştir.

79 Kullanılan resmî yayınların künyeleri dipnotlarda gösterilmiştir.

80 Kullanılan süreli yayınların künyeleri dipnotlarda gösterilmiştir. 
Aydemir, Şevket Süreyya: İhtilâlin Mantı̆̆, 2. bs., İstanbul, Remzi Kitabevi, 1976.

Aydemir, Şevket Süreyya: İkinci Adam: 1938-1950, C.II, İstanbul, Remzi Kitabevi, 1968.

Aydemir, Şevket Süreyya: İkinci Adam: 1950-1964, C.III, İstanbul, Remzi Kitabevi, 1968.

Başgil, Ali Fuat: 27 Mayıs Ihtilali ve Sebepleri, 6. bs., çev. Cemal Aydın, İstanbul, Yağmur Yayınları, 2014.

Celal Bayar: Kayseri Cezaevi Günlüğ̈̈, 3. bs., haz. Yücel Demirel, İstanbul, Yapı Kredi Yayınlar1, 2018.

Cuntasını Deşifre Eden Günlükleri, İstanbul, Zaman Kitap, 2012.

Çelikoğlu, Adnan: Bir Darbeci Subayın Anıları: 27 Mayıs Öncesi ve Sonrası, 2. bs., haz.

Ergin Konuksever, İstanbul, Yapı Kredi Yayınları, 2017.

Demirel, Tanel: “Demokrat Parti İktidarı ve Ordu”, Türkiye’nin 1950’li Ylllarl, 2. bs., haz. Mete Kaan Kaynar, İstanbul, İletişim Yayınları, 2016, s. 267-284.

Demirel, Tanel: Türkiye’nin Uzun On Yll, İstanbul, Bilgi Üniversitesi Yayınları, 2016.

Erer, Tekin: Yassıada ve Sonrası, İstanbul, Rek-Tur Kitap, 1965.

Erkanl1, Orhan: Askerî Demokrasi: 1960-1980, İstanbul, Güneş Yayınları, 1987.

Eroğul, Cem: Demokrat Parti: Tarihi ve İdeolojisi, 5. bs., İstanbul, Yordam Yayınları, 2014. Gülen, Ahmet: Demokratikleşme Sürecinde Mareşal Fevzi Çakmak'ın Siyasî Faaliyetleri (1946-1950), Ankara, Berikan Yayınevi, 2019.

Hale, William: Türkiye'de Ordu ve Siyaset, çev. Ahmet Fethi, İstanbul, Alfa Yayınları, 2014

Heper, Metin: Türkiye'de Devlet Geleneği, 5. bs., çev. Nalan Soyarık, İstanbul, Doğu Batı Yayınları, 2015.

İpekçi, Abdi-Coşar, Ömer Sami: Ihtilâlin Iç̧yüzü, 2. bs., İstanbul, Türkiye İş Bankası Kültür Yayınları, 2012.

Janowitz, Morris: Military Institutions and Coercion in the Developing Nations, Chicago and London, The University of Chicago Press, 1977.

Karaömerlioğlu, Asım: Orada Bir Köy Var Uzakta, 2. bs., İstanbul, İletişim Yayınları, 2011

Karpat, Kemal H.: Asker ve Siyaset, İstanbul, Timaş Yayınları, 2015.

Karpat, Kemal H.: Kimlik ve İdeoloji, İstanbul, Timaş Yayınları, 2017.

Karpat, Kemal H.: Türk Demokrasi Tarihi, İstanbul, Timaş Yayınları, 2016.

Karpat, Kemal H.: Türk Siyasi Tarihi, İstanbul, Timaş Yayınları, 2015.

Kazgan, Gülten: “İzzettin Önder, Ergün Kip ve Çağlar Keyder’in Tebliğlerine İlişkin Yorum”, Türkiye'de Tarımsal Yapılar, der. Şevket Pamuk, Zafer Toprak, Ankara, Yurt 
Yayınlar1, 1988.

Küçük, Sami: Rumeli'den 27 Mayıs'a: İhtilalin Kaderini Belirleyen Köşk Harekâtı, İstanbul, Mikado Yayınları, 2008.

Nalbant, Tamer: Demokrat Parti Döneminde Ordu-İktidar ilişkileri, Ankara Üniversitesi,

Türk İnkılap Tarihi Enstitüsü, Yayımlanmamış Doktora Tezi, 2019.

Oktay, H. Emre: Menderes ’in Gözyaşları: Yassıada, İstanbul, Akis Kitap, 2014.

Öymen, Altan: ... Ve İhtilal, 6. bs., İstanbul, Doğan Kitap, 2014.

Özdemir, Hikmet: Türkiye Cumhuriyeti, İstanbul, İz Yayıncılık, 1995.

Özdoğan, Günay Göksu: “II. Dünya Savaşı Yıllarındaki Türk Alman İlişkilerinde İç ve

Dış Politika Aracı Olarak Pan-Türkizm”, Türk Dış Politikasının Analizi, 3. bs., der.

Faruk Sönmezoğlu, İstanbul, Der Yayınları, 2004, s. 131-147.

Özgüldür, Yavuz: Orgeneral Mustafa Rüşü Erdelhün: 27 Mayıs'tan Yasslada'ya

Siyasetçi-Asker Ekseninde İlginç Bir Portre, İstanbul, İkinci Adam Yayınları, 2018.

Saçlıoğlu, Nahit: Sadık Aldoğan: Bir Özgürlük Savaşçısı, İstanbul, Günlük Ticaret Tesisleri, 1990.

Şahinkaya, Serdar: “29 Nisan 1960〉da Siyasal Bilgiler Fakültesi ve Adım Adım 27

Mayıs", Mülkiye Dergisi, C.34, S.267, 2010, s. 97-121.

Şen, Erdal: Başbakan Adnan Menderes 'in Hayatı: Bir Yiğit Vardl, İzmir, Yitik Hazine Yayınlar1, 2011.

Türkeş, Alparslan: 27 Mayıs, 13 Kasım, 21 Mayıs ve Gerçekler, 2. bs., İstanbul, Dokuz Işık Yayınevi, 1977.

Uğur, Fatih-Gürlek, Mustafa: 50 Yıllık Sır: Genelkurmay Başkanı Erdelhun'un 27 Mayıs Ulay, Sıtkı: “Harbiye Silah Başına!”: 27 Mayıs 1960, İstanbul, Kitapçılık Ticaret Limited Şirketi Yayınları, 1968.

Üskül, Zafer: Siyaset ve Asker: Cumhuriyet Döneminde Sıkıyönetim Uygulamaları, 2. bs., Ankara, İmge Kitabevi, 1997.

Yıldız, Ahmet: İhtilalin İçinden: Anılar, Değerlendirmeler, İstanbul, Alan Yayıncılık, 2001.

Yüksek Adalet Divanı Kararları: 14 Ekim 1960-15 Eylül 1961, İstanbul, Kabalc1 Yayınevi, 2007. 


\section{EKLER}

Ek-1: Birçok emekli üst düzey generalin ordudan tard edilmeleri ve tekrar affedilmelerine dair ardışık belgeler ${ }^{81}$

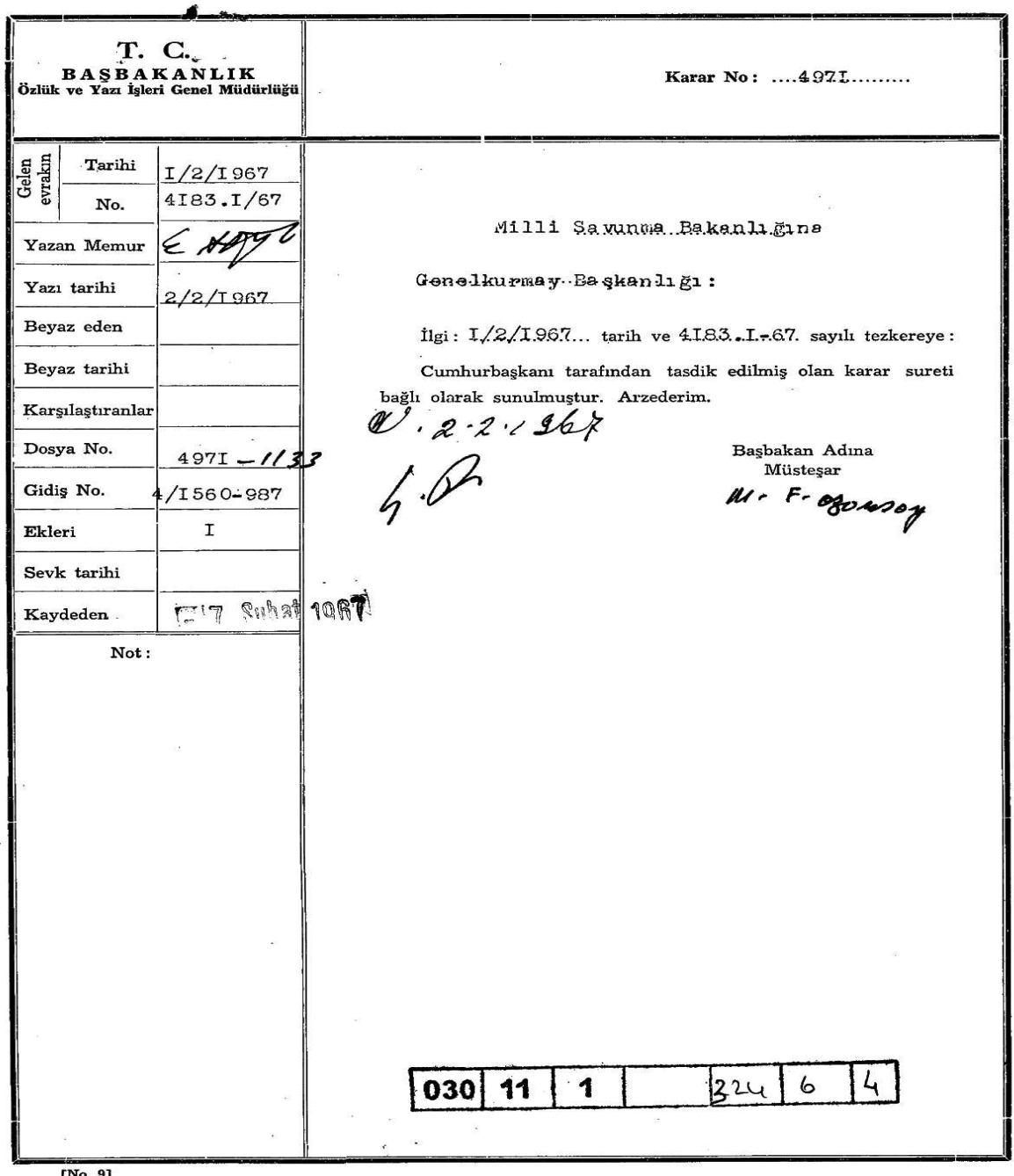

81 BCA, Fon Kodu: 30.11.1.0, Yer No: 324.6.4, 6.2.1967. 
T. C.

GENELKURMAY BASKANLIGI

A N KA R A

PER : 4183- 1-67 (D.5) Gen.Amiral/1

1 SUBAT 1967

KONU : Emekli Generallerin rütbolerinin iades $i$

B A § B A K A N L I Ğ A

- Yüksek Adalet Divanınca verilen hüküm gereğince Ordudan tardına ve yedek subay s ta tüsünden ģıkarılmasına karar verilen aģağıda kimlikleri yazılı emekli generallerin, 780 sayllı Af Kanunu gereğince Yedek Subay s tatüsüne dahil edilmeleri hakkındaki karar yazısı ilisikte sunulmustur.

Tensirlerine arz ederim.

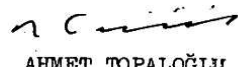

Milli Sa.vunma, Bakanı

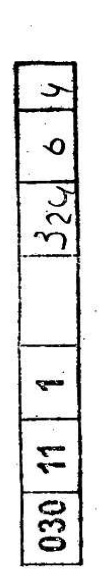

EKI,ER : $\rightarrow$

EK-1 (2 adet karar yaz1s1)

KIMLIKLER I :

1. Em.Org, İshak Avni AKDAĞ

324-11

2. Em.Org. Nazmi ATAÇ

330-3

3. Em.Org. Rüş tü ERDELHUN

330-b-10

4. Em.Org. Nurettin AKNOZ

330-c-11

5. Em.Org. Fevzi UÇANGR

334-125

6. No.Korg • Namבk ARGtJC

7. En. Tümg. Tahsin YAZICI

333-2

8. En.Tümg. Kemal BINATLI

328-3

9. Em.Tuğg. Zihni UNERR

$337-88$

10. Em.Tǚs. Kemal ÇAKIr.

$$
K=4971
$$

333-b-11

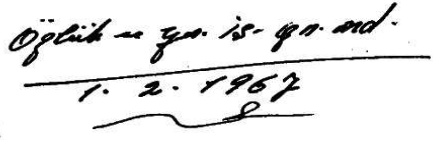

337-120

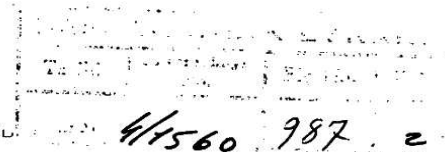




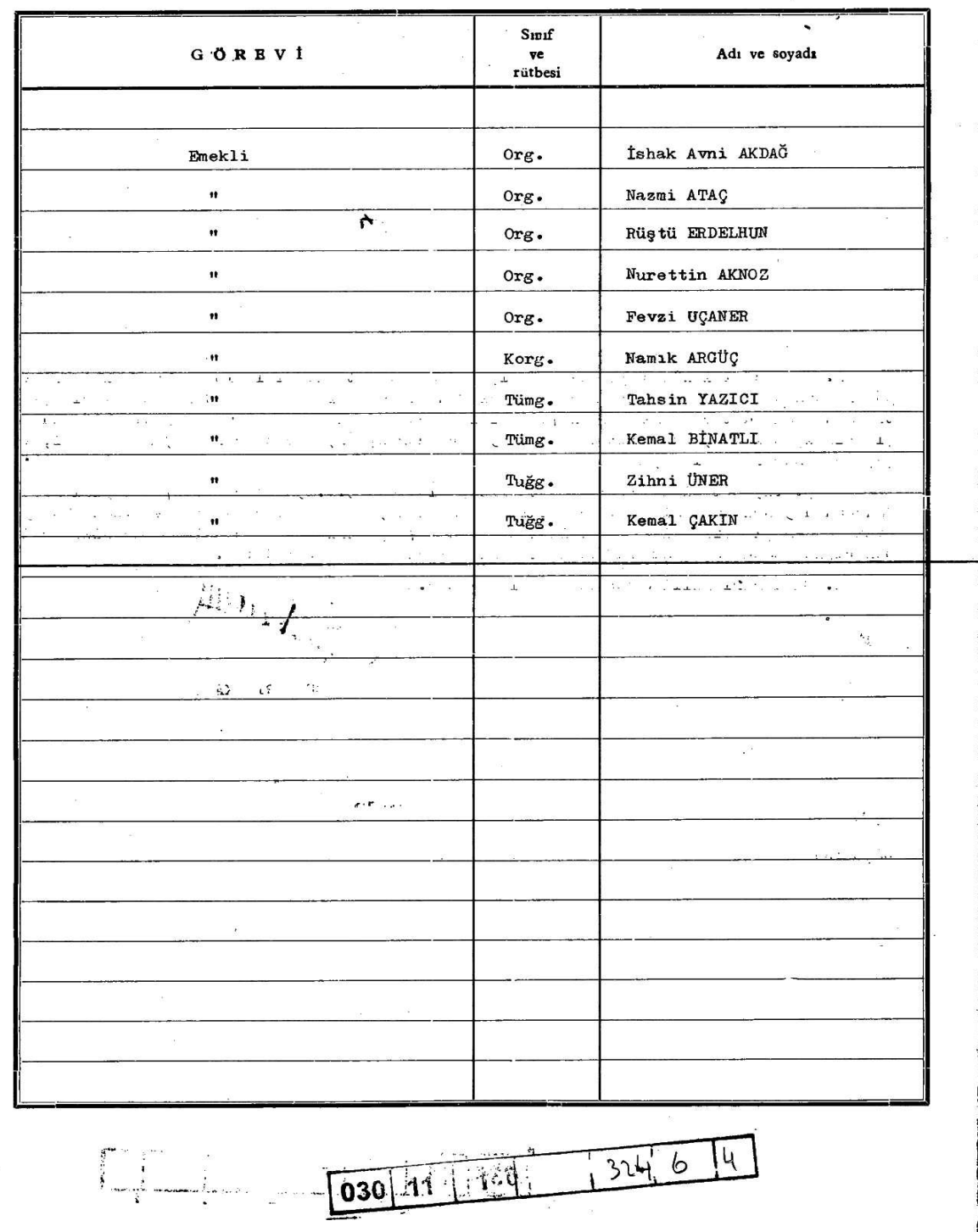




\begin{tabular}{|c|c|c|c|}
\hline \multirow[t]{2}{*}{$\begin{array}{l}\text { Sicil } \\
\text { No. }\end{array}$} & \multirow[t]{2}{*}{ Nasbr } & \multicolumn{2}{|c|}{ DUS UNCELER } \\
\hline & & $\begin{array}{l}\text { Ordudan Tard Kararı } \\
\text { Tarih } \quad-\text { Sayi } \\
\end{array}$ & $\begin{array}{l}\text { Yd.Sb. Sta tiisünden glkarma ka- } \\
\text { rar1. Tarih - Say1 }\end{array}$ \\
\hline $324-11$ & & 15.6 .1962 gün ve 1122 say 211 & . 24.4.1963 gün ve 1739 say1lx \\
\hline $330-3$ & & 15.6 .1962 Gün ve 1120 sayl11 & 24.4 .1963 gün ve 1787 say 111 \\
\hline $330-b-10$ & & 15.6.1962 gün ve 1126 sayilu & $24 \cdot 4.1963$ gün ve 1793 say1l \\
\hline $330-c-11$ & & 15.6.1962 gün ve 1121 saylli & 24.4.1963 gün ve 1788 say 112 \\
\hline $334-125$ & & 15.6.1962 gün ve 1124 sayılı & 24.4 .1963 gün ve 1791 say 211 \\
\hline $333-2$ & & 15.6 .1962 gün ve 1118 gay 211 & 24.4 .1963 gün ve 1786 say 11 \\
\hline $328-3$ & . & 15.6.1962 gün ve 1127 sayil1 & 24.4 .1963 gün ve 1794 say 111 \\
\hline $337-88$ & & 15.6 .1962 gün ve 1123 say 111 & 24.4 .1963 gün ve 1790 say 112 \\
\hline $333-b-11$ & & 15.6.1962 gün ve 1119 say 211 & 6.8 .1963 gün ve 1796 say1l1 \\
\hline $337-120$ & & 15.6.1962 gün ve 1125 say 111 & 24.4.1963 gün ve 1792 say 111 \\
\hline . & & & it \\
\hline & & & 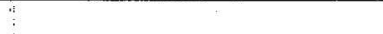 \\
\hline & & & $\cdot$ \\
\hline & & & 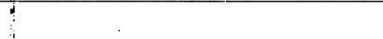 \\
\hline & & & 5 \\
\hline & & . & \\
\hline & & & \\
\hline & & . & \\
\hline & & & 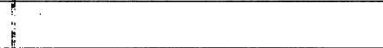 \\
\hline & & & 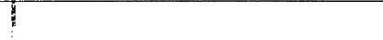 \\
\hline & & & \\
\hline & & & \\
\hline & & & \\
\hline
\end{tabular}

\begin{tabular}{|l|l|l|l|l|l|l|}
\hline 030 & 11 & 1 & & 324 & 6 & 4 \\
\hline
\end{tabular}




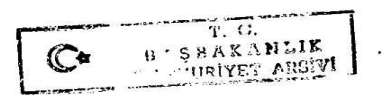

No.:

KA R A R

$1 \quad / 19$

$\therefore$

1. Anayasay ihlal suçundan dolay 2 , Yüksek Adalet Divanının 15 EYLUL 1961 tarih ve 960/1 Esas sayılı hükmü̈ geres̆ince,. Askeri C $C_{\theta} z a$ ve Askeri Muhakeme usulü kanunlarına istinaden Ordudan tard edilen ve 1076 sayılı kanun gereğincede Yedek Subsy a ta tüsünden çikar1lm1g bulunan, bu kararda yaz1l 1 (5) Orgeneral, (1) Korgeneral, (2) Tümgeneral, ve (2) Tuğgeneral hakkında,

9.8.1966 tarihli resmi gazete ile yayinlanan 3.8.1966 tarih ve 780 sayill AF Kanununun 5 nci maddesi 4 ncï bendinin icrasi ile; Ordudan tard edilme ve Yedek Subay Statüsünden ģkarılma işlemlerinin iptali ve 1076 sayllı kanun gereğince emeklilik rütbeleriyle Yedek Subay statüsüne dahil edilmeleri uygun görülmüştür.

2. Bu kararı Milli Savunma Bakanı yürütür.<smiles>CC1=CC1C</smiles>

T.6 Subat 1967

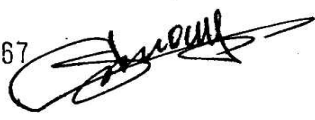

CUMHUR BAŞKANI

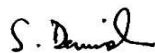

BAŞBAKAN $n \subset$

MİLLİ SAVUNMA BAKANI

\begin{tabular}{|c|c|c|c|c|c|c|}
\hline \begin{tabular}{l|l|l}
030 & 1
\end{tabular} & 11 & 1 & 324 & 6 & & 4 \\
\hline
\end{tabular}


Ek-2: Yarbay Avni Karaca'nın elinden alınan yedek subaylık hakkının kendisine yeniden iade edilmesine dair belge ${ }^{82}$

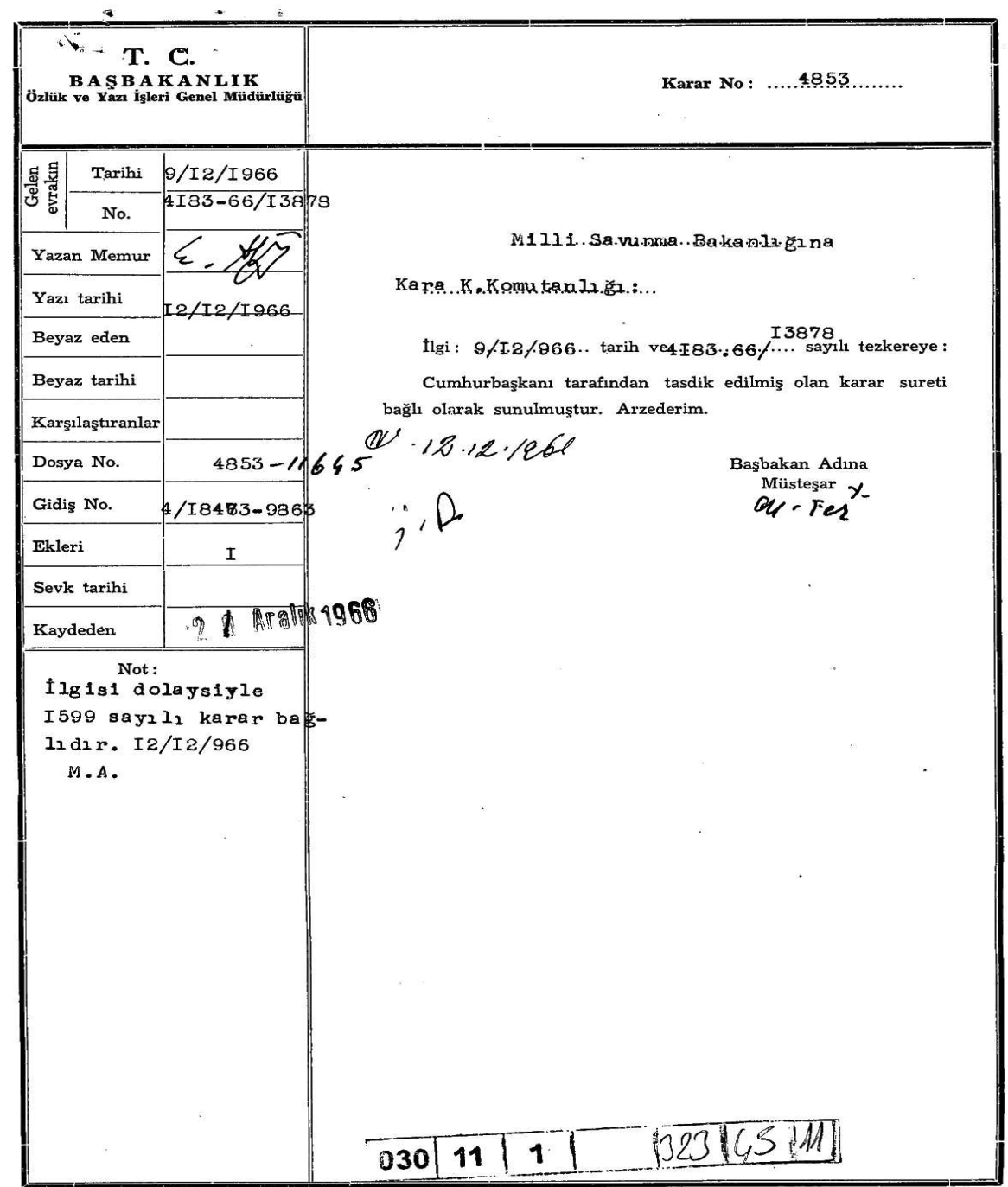

[No. 9] 
Ek-3: Korgeneral Namık Argüç'ün hastalığı nedeniyle cezaevinden affına dair belge $e^{83}$

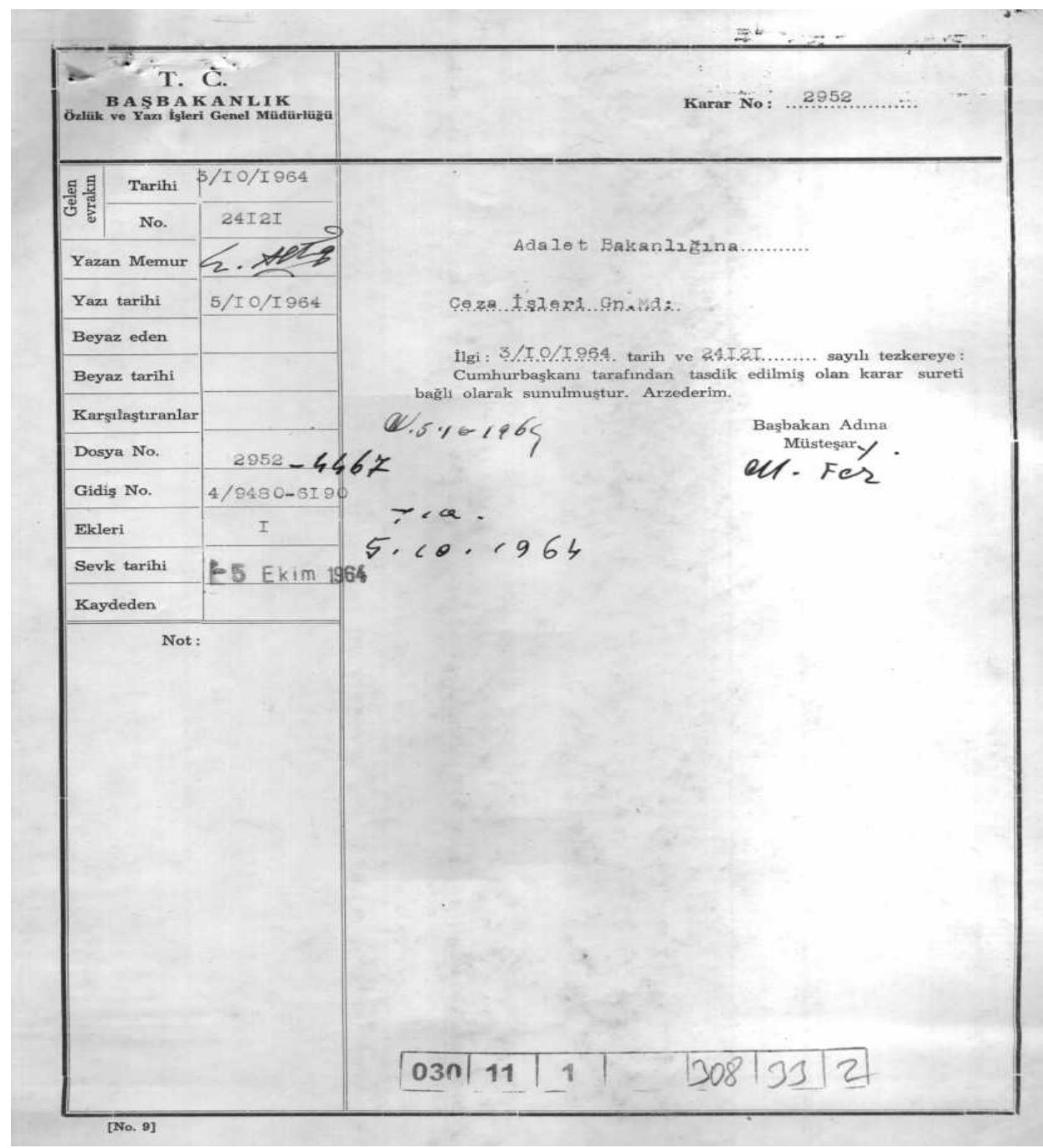

83 BCA, Fon Kodu: 30.11.1.0, Yer No: 308.33.2, 5.10.1964. 